\title{
Does COVID-19 take a breath? The Chinese Current Situation
}

Abdul Qadeer ${ }^{1 \#}$, Muhammad Sohail ${ }^{2 \#}$, Ayesha Younas ${ }^{3}$, Haroon Iqbal ${ }^{4}$, Asif Ullah ${ }^{5}$, Hanif Ullah $^{1}$, Anam Rzzaq ${ }^{4}$, Bouzid Menaa ${ }^{6}$, Ijaz ul Haq ${ }^{7}$, Zulfiqar Ahmed ${ }^{8}$, Fazle Rabbi ${ }^{9}$, Nangial $\mathrm{Khan}^{10}$, Faisal Raza ${ }^{11}$, Saqib Nawaz ${ }^{1}$, Imran Khan ${ }^{12}$, Muhammad Izhar ul Haque ${ }^{13}$, Farid Menaa $^{6^{*}}$

${ }^{1}$ Shanghai Veterinary Research Institute, Chinese Academy of Agricultural Sciences, Key Laboratory of Animal Parasitology of Ministry of Agriculture and Rural Affairs, Shanghai, China.

Email (AQ): qadeerktk848@yahoo.com; Email (HU): dr.hanifullah367@gmail.com, Email (SN) : nawazsaqib143@gmail.com

${ }^{2}$ School of Pharmacy, Collaborative Innovation Center of Advanced Drug Delivery System and Biotech Drugs in Universities of Shandong, Key Laboratory of Molecular Pharmacology and Drug Evaluation, Yantai University, China.

Email (MS): sohailshah11@yahoo.com

${ }^{3}$ College of Pharmaceutical Sciences Zhengzhou University, Zhengzhou, China.

Email (AY): pharmacist.ay@gmail.com

${ }^{4}$ College of Pharmaceutical Sciences, Soochow University, Suzhou, China.

Email (HI): harooniqbal415@hotmail.com (AR): anamrazzaq.ajk@gmail.com

${ }^{5}$ School of Pharmaceutical Sciences, China Pharmaceutical University, Nanjing, Jiangsu, China. Email (AU): $\underline{\text { asif.xhan@gmail.com }}$

${ }^{6}$ Department of Nanomedicine, California Innovations Corporation, San Diego, CA, USA.

Email (BM): bouzid.menaa@gmail.com; Email (FM): $\underline{\text { dr.fmenaa@gmail.com }}$

${ }^{7}$ Jiangsu Food \& Pharmaceutical Science College, Huaian, Jiangsu, China.

Email (IH): ijazbrt@,outlook.com

${ }^{8}$ College of Veterinary Medicine, Sichuan Agriculture University, Chengdu, China.

Email (ZA): vet.zulfiqar@gmail.com

${ }^{9}$ Department of Pharmacy, Abasyn University, Peshawar, Khyber Pakhtunkhwa, Pakistan.

Email (FR): fazle.rabbi@abasyn.edu.pk

${ }^{10}$ State Key Laboratory of Cotton Biology, Institute of Cotton Research of Chinese Academy of Agriculture Sciences, Anyang, China.

Email (NK): nangialkhan@,hotmail.com

${ }^{11}$ School of Pharmacy, Shanghai Jiao Tong University, Shanghai, China. 
Email (FR): faisalraza@sjitu.edu.cn

${ }^{12}$ State Key Laboratory of Animal Nutrition, Institute of Animal Sciences, Chinese Academy of Agricultural Sciences, Beijing, China 100193

Email (IK): Imran_talash76@yahoo.com

${ }^{13}$ The State Key Laboratory of Agricultural Microbiology, College of Veterinary Medicine, Huazhong Agricultural University, Wuhan, 430070, China

Email (MIUH): drizhar@aup.edu.pk

${ }^{\#}$ These authors equally contributed; ${ }^{*}$ To whom the correspondence shall be addressed.

\begin{abstract}
Four new zoonotic coronaviruses outbreak occurred during the previous two decades. The first coronavirus outbreak happened in 2003 and was named Severe Acute Respiratory Syndrome Coronavirus-1 (SARS-CoV-1), followed by Middle East Respiratory Syndrome Coronavirus (MERS-CoV) in 2013, and by Swine Acute Diarrhoea Syndrome (SADS) in 2017. In late December 2019, a patient from Wuhan Seafood Wholesale Market, China, was allowed to Huang's hospital with respiratory distress syndrome (RDS) of apparently unknown etiology, which later was diagnosed with SARS-CoV-2-induced coronavirus disease-19 (COVID-19). SARS-CoV-2 was isolated from a different clade of the subgenus Sarbecovirus of the genus Betacoronavirus. This new CoV variant showed $96.2 \%$ similarity to bat coronavirus. Actually, based on genetic studies, pangolin, bats and snakes are suspected to be a possible intermediate host of this virus, but further research is in progress to determine how this virus appeared and What exactly is the cause of infection?. The SARS-CoV-2 outbreak has higher transmissibility, contagiosity and pathogenicity compared to that of SARS-CoV-1 and MERS-CoV. SARS-CoV2 swiftly spread from continent to continent and is persistently causing a shocking global public health concern albeit the rate of infected cases and mortality is relatively decreasing over time.

This review is focusing on the origin, transmissibility, etiology, epidemiology, and evolution of COVID-19. We also highlight the current diagnostics, therapies, and prognostics for SARSCoV-2. Eventually, we report and provide our humble opinion about the preventive strategies to control the ongoing related pandemic situation at global and individual levels, considering the international public health emergency and possible future epidemics and pandemics.
\end{abstract}

Keywords: SARS-CoV-2; COVID-19; Genetics; Epidemiology; Theranostics; Vaccines and Preventive Infectiology. 


\section{Introduction}

The COVID-19 pandemic situation is reminiscent of Wolfgang Petersen's 1995 American medical disaster film "Outbreak," which was created on Richard Preston's nonfiction book "The Hot Zone." Indeed, COVID-19, initiated by SARS-CoV-2, is a new evolving, rapidly developing illness that requires immediate intervention due to its high spread mortality rates in a very petite epoch of time

Meanwhile the beginning of the $21^{\text {st }}$ century, the widespread of contagious infections have taken a significant toll on humans. In the end of December 2019, a large number of patients with influenza-like illnesses, pneumonia-like disorders arisen in Wuhan, Hubei, China (Huang et al., 2020a). Despite the unknown exact etiology of these diseases and drastic containment measures, their incidence drastically increased. As a result, samples from the lower respiratory tract were subjected to comprehensive sequencing, resulting in the discovery of SARS-CoV-2, the agent of etiology of the COVID-19-induced pandemic (Huang et al., 2020a).

Based on the International Committee on Taxonomy of Viruses, the WHO formally termed this virus "SARS-CoV-2"-induced disease was named 'COVID-19" (Gorbalenya et al., 2020). According to phylogenetic analysis, COVID-19 is a ssRNA virus that belongs to the order Nidovirales, family Coronaviridae, sub-family Orthocoronavirinae, and subgenus Sarbecovirus of the genus Betacoronavirus, (Beta-CoV) (Zhu et al., 2020). Indeed, SARS-CoV-2 (further abbreviated as SARS-2) is a Beta-CoV with a genetic sequence similarity of at least $70-85 \%$ to SARS-like CoV-1 (aka SARS1) (Zhu et al., 2020).

SARS-2 outbreak is the $3^{\text {rd }}$ coronavirus that has appeared in the human population over the past 20 years following SARS-1 in 2003 and MERS-CoV in 2013, and the seventh in the coronavirus $(\mathrm{CoV})$ family that has infected individuals to date (Huang et al., 2020a). Since the very beginning of SARS-2 outbreak, China reacted rapidly by reporting to the WHO and sharing the sequence information of SARS-2 with the international community (Munster et al., 2020).

It's worth noting that coronaviruses (CoVs) present in humans and animals caused hepatic, enteric, respiratory and neurological problems of varying severity (Weiss and Leibowitz, 2011). CoVs are divided into 4 genera: (i) $\alpha$-coronavirus, (ii) $\beta$-coronavirus, (iii) $\gamma$-coronavirus, and (iv) $\delta$-coronavirus. $\beta$-coronavirus (i.e. SARS-CoVs) are categorized into 4 lineages $\mathrm{A}, \mathrm{B}$, C, and D (De Groot, 2011). In 2018, the $\beta$-coronavirus lineages were reclassified and renamed as Sarbecovirus (old name lineage B), Nobecovirus (old name lineage D), Merbecovirus (old name lineage C) and Embecovirus (old name lineage A) (Wong et al., 2019). Probably, the most well studied $\mathrm{CoVs}$ to date are $\beta$-coronaviruses, such as murine coronavirus (MuCoV) and mouse hepatitis virus (MHV), that have served as model organisms for research into CNS diseases including acute hepatitis, multiple sclerosis and encephalitis (Pyrc et al., 2007).

Despite the fact that CoVs normally only cause "common cold-like symptoms" in humans, SARS-CoVs showed the potential for more severe human disease as a result of CoVs infections (Weiss and Leibowitz, 2011). Indeed, soon after the SARS-related human coronavirus (HCoV) was discovered, new CoVs were discovered in humans associated with more serious infections. 
As a result, NL63 is a coronavirus that causes bronchiolitis in children, while HKU1 is a coronavirus that causes chronic respiratory disease in the aged peoples (Pyrc et al., 2007). CoVs have a high incidence of recombination (Graham and Baric, 2010). And, likewise other RNA viruses, elicit high mutation rates leading to a rapid variation in new host and environment (Holmes and Rambaut, 2004). These features provide to (at least a number of) these zoonotic viral pathogens an opportunity to acclimate and efficiently spread with virulence among the human population (Wang et al., 2020a). Nevertheless, it is vital to mention that SARS-2 is less pathogenic (Munster et al., 2020). Albeit more contagious than SARS-1 and MERS based on the current number of infected cases (Ashour et al., 2020). Thereby, MERS-CoV showed 35\% of case mortality rate while SARS-1 had a $9.6 \%$ case fatality rate when the rate mortality is compared to the number of infected (confirmed as positive) patients (Deng and Peng, 2020). According to the worldometer, Coronovirus update, the case casualty rate of SARS-CoV-2 was almost $7 \%$ until July, $10^{\text {th }}$ 2020. Both SARS-CoV-1 and SARS-CoV-2 viruses displayed a nosocomial transmission and a zoonotic importance (Hui et al., 2020).

Bats are believed to be the originators of SARS-1 (Cui et al., 2019), and its intermediate source is presumed to be civets (cat-like animals) from the wet markets in Guangdong (Hui and Zumla, 2019). The current epidemic of viral pneumonia due to SARS-2 stances momentous fears to global health and could be correlated to the Chinese wildlife trade, although numerous queries remain unanswered about the origin of this new infection outbreak.

SARS-2 seems to be transmitted from animals such as bats, pangolins to humans, and this statement remains unclear to date. Although the diagnosis is now relatively well-established (outside of possible false positive or false negative results), there are currently minimal clinical details about the SARS-CoV-2's mode of infection, viral origin, transmission route, incubation period, epidemic curve, pathogenesis, autopsy findings and treatment response among the severe cases (Hui et al., 2020).

In this review, we give an update on the original source, transmissibility, etiology, epidemiology, evolution, of COVID-19. We also highlight the current diagnostics, therapies, and prognostics for this new disease. Eventually, we report possible preventive strategies to fight such pandemic situations.

\section{Description, Source and History of COVs}

CoVs are ssRNA viruses that are enveloped, non-segmented, and positive-sense (Cui et al., 2019), and the virus particles size ranged from 70-90 nm (Kim et al., 2020). These nanoorganisms have the largest genomes (26 to 32 kilobases) of RNA viruses, and their crownlike morphology under electron microscopy gained them the name "coronaviruses" ( $\mathrm{Su}$ et al., 2016).

Humans and animals are the primary hosts of CoVs, and they have differing degrees of magnitude in their effects on the gastrointestinal, enteric, hepatic, and neurological processes (Weiss and Leibowitz, 2011). Zoonotic CoVs were known since 1930s (Cunningham and Stuart, 1947), and the first human coronavirus 229E strain was isolated from an untreated patient's 
respiratory tract in 1966 (Ye et al., 2020). CoVs were known to be lowly pathogenic before the SARS-1 outbreak in Guangdong province, China in 2002/2003 (Ksiazek et al., 2003; Zhong et al., 2003). Further, a new extremely pathogenic coronavirus, namely MERS-CoV, arose from Saudi Arabia (Zaki et al., 2012). Market civets and dromedary camels, respectively, transmitted SARS-1 and MERS-CoV to humans (Alagaili et al., 2014), despite the fact these viruses were believed to have instigated in bats (Ithete et al., 2013; Yang et al., 2015). In late December 2019, a further outbreak called SARS-2 arose from Wuhan located in the central China's Hubei Region (Huang et al., 2020a). Although the origin of this novel CoV might be multi-sources, the first cluster of patients suffering from RDS of unidentified source and admitted to Wuhan Jinyintan, were all originated from Wuhan Seafood Wholesale Market (Zhu et al., 2020).

It's difficult to pinpoint the virus's origin and evolutionary course that might lead to a pandemic outbreak. These findings will help researchers understand the molecular structure of the virus's cross-spread and devise a strategy to stop it from spreading further. As a result, the first cases of SARS-2 being linked to the Wuhan (Huanan) Seafood Wholesale Market presented indication that the disease spread from there (Huang et al., 2020a; Li et al., 2020c). Whatever the origin of this outbreak is, the first documented patient was linked to this market (Huang et al., 2020a). SARS-2 analysis for origin determination was initially performed from six patients based on their genome sequence (Xu et al., 2020a). When compared to MERS-CoV, the genomic data of SARS-2 exhibited a much higher homology with that of SARS-1 (Xu et al., 2020a). In spite of the detail 6 main open-reading frames (ORFs) of SARS-2 genes pooled less than $80 \%$ nucleotide acid distinctiveness with SARS-1, the seven conserved replicas domains in ORF1ab in SARS-2 shared 94.6 percent amino acid sequence identity with SARS-1, implying that the two viruses may belong to the same species (Zhou et al., 2020a; Zhou et al., 2020b).

The detection of a transitional animal's host has sparked a lot of interest. SARS-2 belonged to the Betacoronavirus genus Sarbecovirus, which is diligently associated to two SARS-like COVs, resultant from bats, bat-SL-CoVZC45 and bat-SL-CoVZXC21 (Lu et al., 2020c; Xu et al., 2020a). Despite this, SARS-2 shared just 96.2 percent of its genome with the CoV RaTG13, which was isolated from Rhinolophus affinis bats (Zhou et al., 2020a; Zhou et al., 2020b). Nonetheless, some SARS-CoVs (SARS-1, SARS-2, and MERS) use human angiotensinconverting enzyme 2 (ACE2), which has also been discovered in bats. Indeed, serological tests revealed that the human infection in Yunnan Province was caused by SARS-1, which was spread by bats (Fan et al., 2019; Wang et al., 2018). Agreeing to new studies, SARS-1 mostly taints ciliated bronchial epithelial cells and type II pneumocytes and usages ACE2 as a binding receptor (Kuhn et al., 2004). While MERS-CoV, has been shown to contaminate type II pneumocytes and unciliated bronchial epithelial cells using the dipeptidyl peptidase 4 (DPP4 aka CD26) receptor (Lu et al., 2013). Based on environmental distribution, genetic diversity, interspecies spreading, and pathogenesis, SARS-1 and MERS CoVs are supposed to be initiated in bats (Cui et al., 2019). Other outlets, however, have been investigated or are being investigated. Snakes were proposed as a potential intermediate host of SARS-2 because of its genetic proximity to SARS-2, its biassed relative synonymous codon use (RSCU), and homologous recombination within the spike glycoprotein (gp), which could lead to cross-species spread from snake to humans (Ji et al., 2020b). Later, it was claimed that a Malayan pangolin (Manis javanica) was a potential intermediate host for SARS-2 (Liu et al., 2019). Indeed, the 
pangolin $\mathrm{CoV}$ genome analysis revealed novel CoVs representing two sub-lineages related to SARS-2, i.e. GD/P1L and GDP2S, with $85.5 \%$ to $92.4 \%$ similarity, respectively (Lam et al., 2020). The SARS-2 receptor ACE2 from bat and pangolin and several other species, were found to resemble to that ACE2 receptor in humans (Luan et al., 2020). Leaving aside the human adaptation hypothesis, animal selection theory recommends that SARS-2 was present in various animal classes prior to human infection (Yuan et al., 2020). Natural selection would most likely be more effective in an animal host with a high population density, allowing a forerunner virus to evolve genomic morphology appropriate for human ACE2 receptor binding (Andersen et al., 2020). Due to genomic variations, the positions of bats, snakes, and pangolins as potential natural reservoirs and intermediate hosts need to be studied further. To date, no animal $\mathrm{CoV}$ sufficiently similar to SARS-2 was identified as the direct progenitor of SARS-2 (Andersen et al., 2020). Thus, conclusive results for definite evidence are still awaited.

The current the possible origin, intermediate and final hosts of SARS-1, MERS, and SARS-2 CoVs is concise in Figure 1. The putative cycle of transmission by SARS-2 is presented in Figure 2.
Origin
Intermediate Host Transmission
Final Host
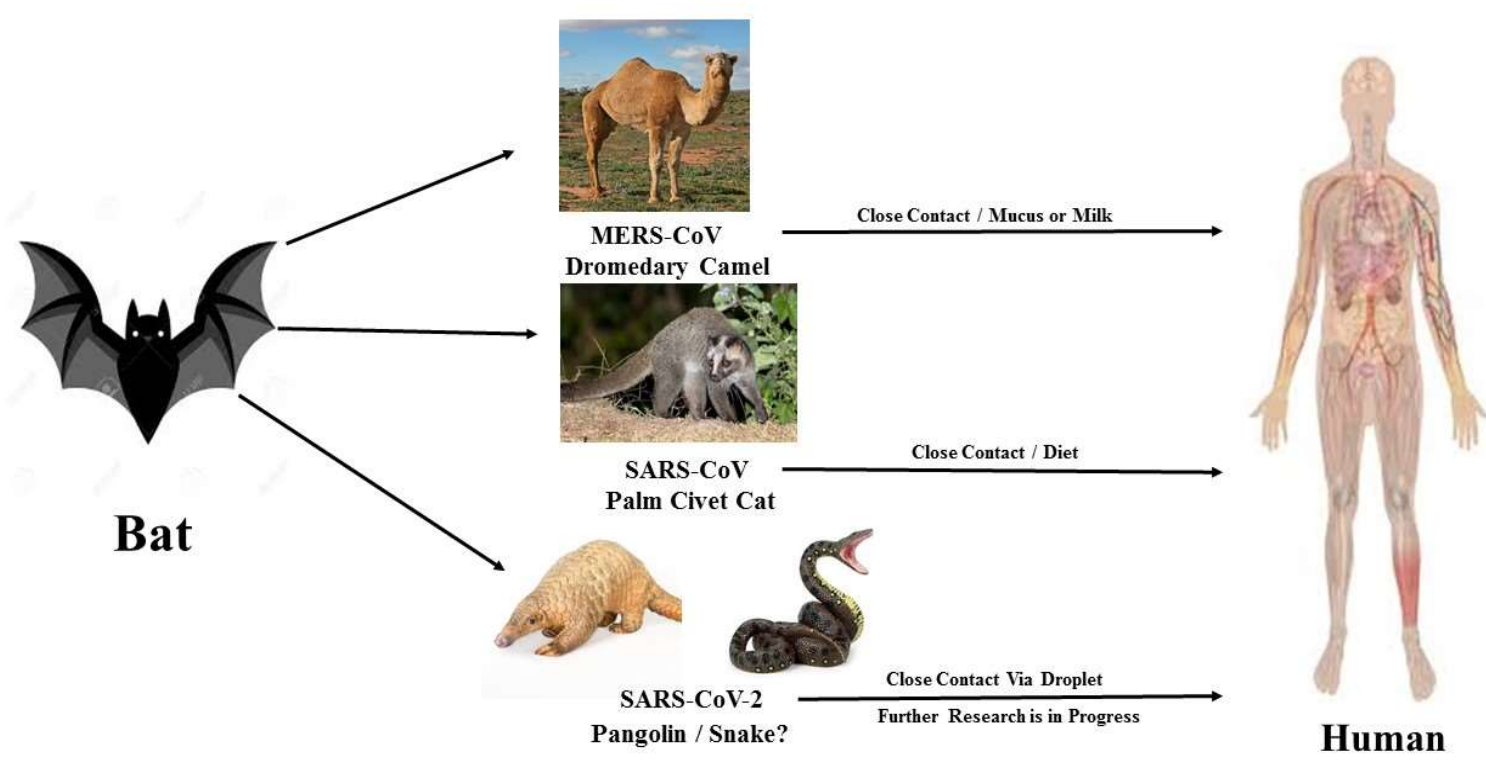

Figure 1. Origin, intermediate and final hosts of SARS-CoV-1, MERS-CoV, and SARS-CoV-2. Bat is considered the origin of all three outbreaks based on genomic studies. The intermediate host and way of transmission of MERS and SARS are known but further related research about SARS-2 is still in progress. 


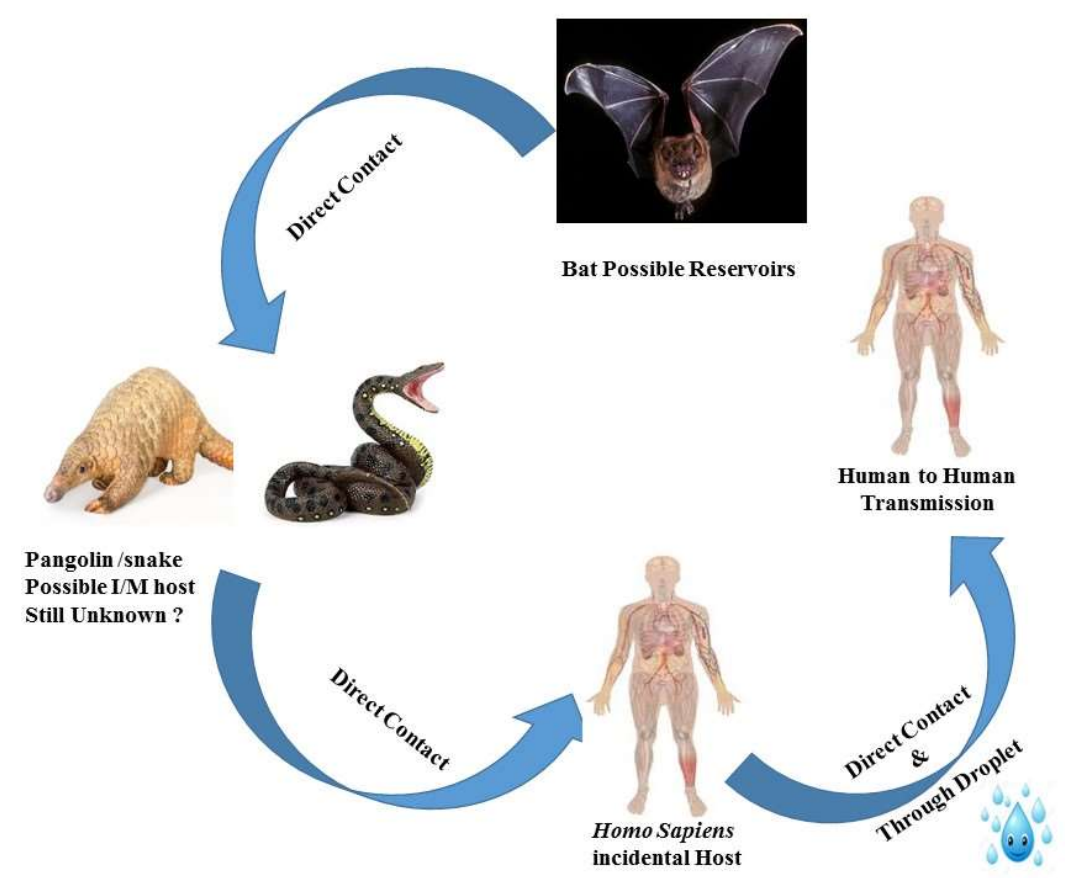

Figure 2. Putative transmission cycle by SARS-CoV-2. Bat is known to be the reservoir host according to genomic studies. Pangolin and snake might be intermediate hosts based on genomic identity. The transmission is thought to be by direct contact and/or droplets during sneezing and cough.

\section{COVID-19 Epidemiology}

At the end of 2019, Chinese authorities issued an alert to WHO about an unexplained etiology RDS outbreak in Wuhan, Hubei Province, China (WHO, 2020d). The Chinese Centre for Disease Control and Prevention (CDC) discovered a new coronavirus from the sample from the throat of a patient in January 2020, and WHO named it 2019-nCoV (Chen et al., 2020b). The main cluster of reported cases had epidemiological associations to a live animal market, implying a zoonotic foundation (WHO, 2020c). As of 09 July 2020, there were 12,164,173 cases, and 552,029 deaths in about 215 countries and territories around the world (Worldometer, 2020a). The majority of cases were observed in the United States, Brazil, India, Russia, Peru, Chile, Spain, the United Kingdom, Mexico, Iran, and Pakistan, in that order (Worldometer, 2020a). Present clinical and epidemiological data are inadequate to completely comprehend the diseases' spectrum. Figure 3 depicts the total deaths, daily new cases, and cumulative cases in China from January 20, 2020 to March 1, 2020. Briefly, the daily new cases in the Chinese population reached a peak (14108) on February 12th, 2020 before a strong decline of reported new cases was noticed from March $1^{\text {st }}, 2020$ (Worldometer, 2020b). 


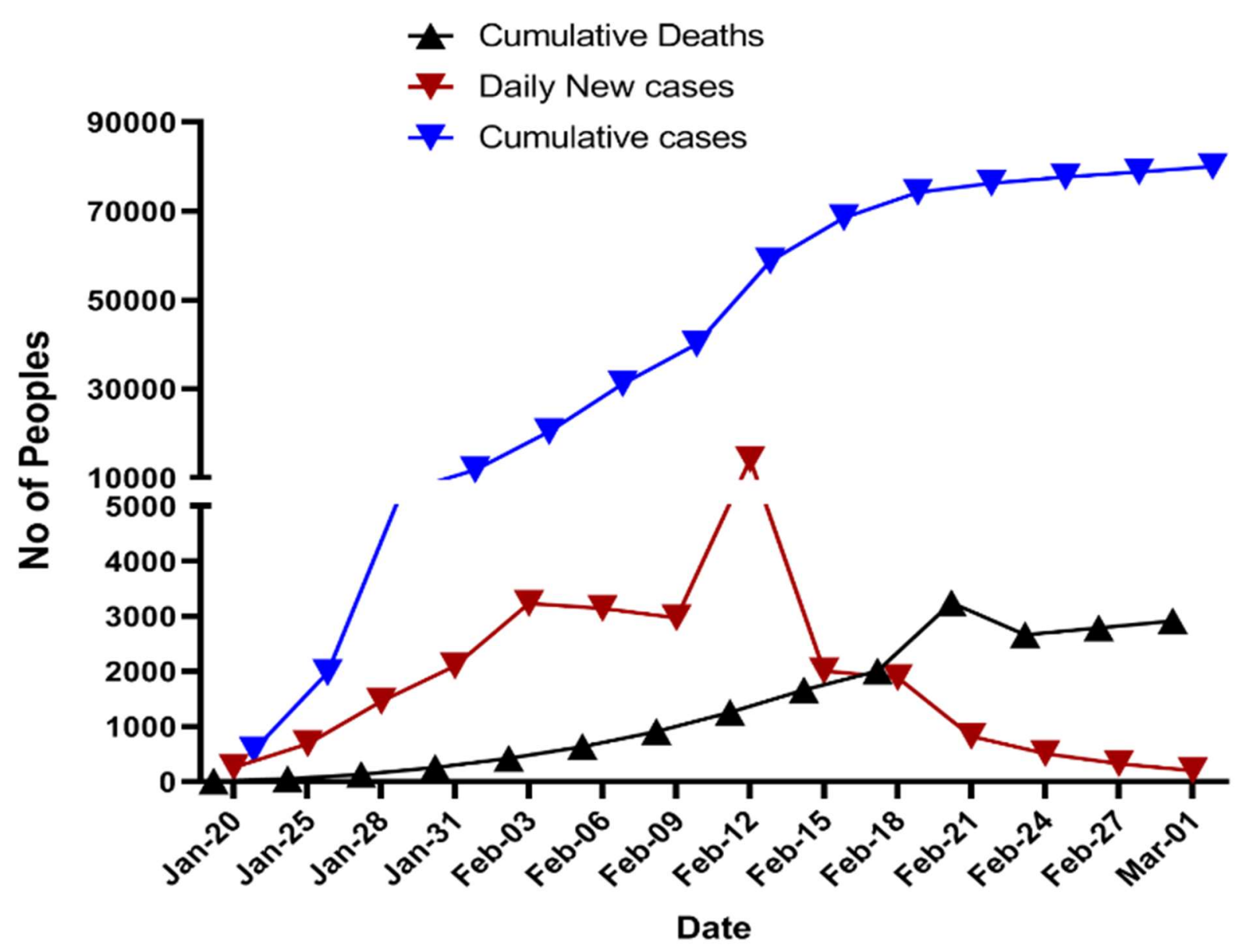

Figure 3. Daily cumulative, emerged, and fatal confirmed cases of COVID-19 in mainland China. As of February 12th, 2020, the daily new cases reached his summum. After February 12, while the cumulative number of deaths continued to grow faster, the daily new cases started to decline and on March $1^{\text {st }}$ the new cases reached 202, which was considered as a "negligible number". On March 1st, 2020, cumulative cases and cumulative deaths reached 80026 and 2912 , respectively (Worldometer, 2020b).

Over 3 billion people was predicted to daily travel during the period between January 10th to February 18th, which could have increased the virus spread (Read et al., 2020). By July 10th, 2020, the worldwide COVID-19 mortality rate was about $7 \%$ (total death * 100/total cases) and was about $6 \%$ (total death * 100/total cases) in China among the confirmed cases (Worldometer, 2020a), which is lower as compared to SARS-1 (9.6\%) and much lower (about 5 folds) than MERS (34.4\%). COVID-19's outbreak is extremely dangerous due to its high virulence (Deng, 2020). In China, the median age of the first 99 COVID-19 confirm cases was 55.5 years old, compared to 41.3 and 52.8 years for SARS-1 and MERS, respectively (Chen et al., 2020b; Deng and Peng, 2020). The epidemiological data from China compared to the 23 other most infected countries by COVID-19 at July 10th, 2020, is given in Table 1. 
Table 1. Epidemiological data of most affected countries by COVID-19 (classified by descending order), according to (Worldometer, 2020a).

\begin{tabular}{|c|c|c|c|c|c|}
\hline $\begin{array}{c}\text { Country } \\
\text { name }\end{array}$ & $\begin{array}{c}\text { Total number } \\
\text { of COVID- } \\
\text { positive } \\
\text { patients }\end{array}$ & $\begin{array}{c}\text { Total deaths } \\
\text { from } \\
\text { infected } \\
\text { Patients }\end{array}$ & $\begin{array}{c}\text { Total } \\
\text { recovered } \\
\text { patients from } \\
\text { COVID-19 }\end{array}$ & $\begin{array}{c}\text { Mortality } \\
\text { rate due to } \\
\text { COVID-19 } \\
(\%)\end{array}$ & $\begin{array}{c}\text { Prevalence } \\
\text { rate due to } \\
\text { COVID-19 } \\
(\%)\end{array}$ \\
\hline$\overline{\text { USA }}$ & $3,219,999$ & 135,822 & $1,426,428$ & 9 & 8.01 \\
\hline Brazil & $1,759,103$ & 69,254 & $1,152,467$ & 6 & 39.36 \\
\hline India & 794,842 & 21,623 & 495,960 & 4 & 7.40 \\
\hline Russia & 707,301 & 10,843 & 481,316 & 1.53 & 3.21 \\
\hline Peru & 316,488 & 11,314 & 207,802 & 3.58 & 17 \\
\hline Chile & 306,216 & 6,682 & 274,922 & 2 & 24.74 \\
\hline Spain & 300,136 & 28,401 & N/A & 9.47 & 5.23 \\
\hline UK & 287,621 & 44,602 & $\mathrm{~N} / \mathrm{A}$ & 15.51 & 2.55 \\
\hline Mexico & 282,283 & 33,526 & 172,230 & 16 & 40.33 \\
\hline Iran & 250,458 & 12,305 & 212,176 & 5 & 13.20 \\
\hline Italy & 242,363 & 34,926 & 193,978 & 15 & 4.4 \\
\hline Pakistan & 240,848 & 4,983 & 145,311 & 3 & 16.15 \\
\hline $\begin{array}{l}\text { South } \\
\text { Africa }\end{array}$ & 238,339 & 3,720 & 113,061 & 1.60 & 11.91 \\
\hline $\begin{array}{c}\text { Saudi } \\
\text { Arabia }\end{array}$ & 223,327 & 2,100 & 161,096 & 1 & 10.51 \\
\hline Turkey & 209,962 & 5,300 & 190,390 & 2.53 & 5.48 \\
\hline Germany & 199,198 & 9,125 & 183,600 & 5 & 3.12 \\
\hline Bangladesh & 175,494 & 2,238 & 84,544 & 1.28 & 19.33 \\
\hline France & 170,094 & 29,979 & 78,170 & 28 & 12.3 \\
\hline Colombia & 133,973 & 4,714 & 56,272 & 3.52 & 14.2 \\
\hline Canada & 106,805 & 8,749 & 70,574 & 11 & 3.45 \\
\hline Qatar & 102,110 & 142 & 97,272 & 0.139 & 25.49 \\
\hline
\end{tabular}




\begin{tabular}{|c|c|c|c|c|c|}
\hline Argentina & 90,693 & 1,720 & 38,313 & 4 & 20.9 \\
\hline China & 83,585 & 4,634 & 78,609 & 6 & 0.092 \\
\hline
\end{tabular}

\section{Classification and Diversity}

CoVs belong to the family of Orthocoronavirinae subfamily of the Coronaviridae and the Nidovirales order (Fan et al., 2019). The members of the Coronavirinae subfamily are further categorized based on their genomic structure and phylogenetic relationships (Cui et al., 2019). While $\alpha$-CoVs (e.g. TGEV, Colacovirus, PEDV, HCoV-NL63 and HCoV-229E) and $\beta$-CoVs (e.g. SARS-CoVs, MERS-CoV, HCoV-OC43, HKU1, MHV) can only infect mammals, the $\gamma$ CoVs (e.g. avian $\mathrm{CoV}$, beluga whale $\mathrm{CoV}$ ) and $\delta$-CoVs (e.g. HKU11, HKU15, common moorhen $\mathrm{CoV}$, night heron $\mathrm{CoV}$, wigeon $\mathrm{CoV}$, white eye $\mathrm{CoV}$, thrush $\mathrm{CoV}$ ) can infect both birds and mammals (Woo et al., 2012). $\alpha$-CoVs and $\beta$-CoVs represent the primary source of RDS in humans and gastrointestinal diseases in animals (Cui et al., 2019). $\beta$-CoVs can induce slight upper respiratory diseases in immune competent hosts (Forni et al., 2017a; Su et al., 2016), while the $\gamma$-CoVs can cause a highly contagious upper respiratory diseases in domestic chickens (Thor et al., 2011). The classification and comparison of $\alpha, \beta, \gamma$ and $\delta \mathrm{CoVs}$ are provided in Table 2.

Table 2. Taxonomy and classification of alpha, beta, gamma, and beta coronaviruses. (Decaro, 2011a, b, c; ViralZone; Wrapp and McLellan, 2019)

\begin{tabular}{|c|c|c|c|c|}
\hline $\begin{array}{l}\text { Virus name } \\
\text { Features }\end{array}$ & alpha-CoVs & Beta-CoVs & Gamma-CoVs & Delta-CoVs \\
\hline Order & Nidovirales & Nidovirales & Nidovirales & Nidovirales \\
\hline Family & Coronaviridae & Coronaviridae & Coronaviridae & Coronaviridae \\
\hline Subfamily & Coronavirinae & Coronavirinae & Coronavirinae & Coronavirinae \\
\hline Genus & Alphacoronavirus & Betacoronavirus & Gammacoronavirus & Deltacoronavirus \\
\hline $\begin{array}{l}\text { Subgenera } \\
\text { and species }\end{array}$ & $\begin{array}{l}\text { TGEV, Colacovirus, } \\
\text { PEDV, HCoV-NL63, } \\
\text { HCoV-229E, and } \\
\text { some bat CoVs }\end{array}$ & $\begin{array}{c}\text { SARS-CoVs, } \\
\text { MERS-CoV, } \\
\text { SARS-CoV-2, } \\
\text { HCoV-OC43, } \\
\text { HKU1, MHV, } \\
\text { and some bat } \\
\text { CoVs }\end{array}$ & $\begin{array}{c}\text { Avian CoV, Beluga } \\
\text { whale CoV, } \\
\text { (BWCoV SW1) }\end{array}$ & $\begin{array}{c}\text { Bulbul CoV } \\
\text { (HKU11), Porcine } \\
\text { CoV (HKU15), } \\
\text { Night heron CoV, } \\
\text { Wigeon CoV, } \\
\text { Common moorhen } \\
\text { CoV, White eye } \\
\text { CoV, Thrush CoV }\end{array}$ \\
\hline Genome & $\operatorname{ssRNA}(+)$ & $\operatorname{ssRNA}(+)$ & $\operatorname{ssRNA}(+)$ & ssRNA $(+)$ \\
\hline Size & $27-32 \mathrm{~kb}$ & $27-32 \mathrm{~kb}$ & $27-32 \mathrm{~kb}$ & $26-26.5 \mathrm{~kb}$ \\
\hline
\end{tabular}




\begin{tabular}{|c|c|c|c|c|}
\hline Morphology & Spherical & Spherical & Spherical & Spherical \\
\hline Diameter & $120-160 \mathrm{~nm}$ & $120-160 \mathrm{~nm}$ & $120-160 \mathrm{~nm}$ & $120 \mathrm{~nm}$ \\
\hline Infectivity & $\begin{array}{l}\text { Human, swine, dogs, } \\
\text { cats, bats }\end{array}$ & $\begin{array}{l}\text { Humans, cattle, } \\
\text { swine, dogs, } \\
\text { horses, ruminant }\end{array}$ & $\begin{array}{l}\text { Domestic fowl, } \\
\text { turkeys, and other } \\
\text { birds }\end{array}$ & $\begin{array}{l}\text { Birds and } \\
\text { Mammals }\end{array}$ \\
\hline $\begin{array}{l}\text { Entry } \\
\text { mechanism }\end{array}$ & $\begin{array}{l}\text { Receptor-mediated } \\
\text { endocytosis }\end{array}$ & $\begin{array}{l}\text { Receptor- } \\
\text { mediated } \\
\text { endocytosis }\end{array}$ & $\begin{array}{l}\text { Receptor-mediated } \\
\text { endocytosis }\end{array}$ & $\begin{array}{l}\text { Receptor-mediated } \\
\text { endocytosis }\end{array}$ \\
\hline $\begin{array}{l}\text { Site of } \\
\text { replication }\end{array}$ & Cytoplasm & Cytoplasm & Cytoplasm & Cytoplasm \\
\hline $\begin{array}{l}\text { Structural } \\
\text { component }\end{array}$ & $\begin{array}{l}\text { Core, capsid, } \\
\text { envelope }\end{array}$ & $\begin{array}{l}\text { Core, capsid, } \\
\text { envelope }\end{array}$ & $\begin{array}{c}\text { Core, Nucleocapsid, } \\
\text { envelope }\end{array}$ & Nucleocapsid \\
\hline
\end{tabular}

Both CoVs in humans, according to existing sequencing databases, are of animal origin. MERS (-CoV), HCoV-NL63 (-CoV), SARS (-CoV), and HCoV-229 (-CoV) are all believed to have found in bats, while rodents are the source of HCoV-OC43 (-CoV) and HKU1 (-CoV) (Forni et al., 2017b; Su et al., 2016). SARS and MERS spread through domestic animals to animals and humans whereas the domestic animals themselves can be subjected from a disease triggered by bat-borne or closely related CoVs (Cui et al., 2019). In bats, genomic sequences that are strikingly near to the Porcine Epidemic Diarrhea Virus (PEDV) have been discovered (Huang et al., 2013; Lacroix et al., 2017), and SADS-COV is a recently spread from bats to pigs (Zhou et al., 2018).

In SARS-CoVs, the most common recombination occurs upstream of ORF8 and inside the $\mathrm{S}$ gene, which codes for the spike (S) protein that covers the receptor-binding domain (RBD) (Hon et al., 2008; Hu et al., 2017; Wu et al., 2016). CoVs elicit a high genomic alteration rate, which leads to high diversity of the host receptor adaptation (Graham and Baric, 2010; Sabir et al., 2016). The occurrence and genetic multiplicity of bat SARS related-CoVs (SARSr-CoVs) showed frequent recombination, and a novel variant was therefore expected to arise in the future (Nagy and Simon, 1997). This hypothesis became true in late December 2019 in the form of 2019-nCoV/SARS-CoV-2/COVID-19. 


\section{Origin Intermediate Host Transmission $\quad$ Final Host}
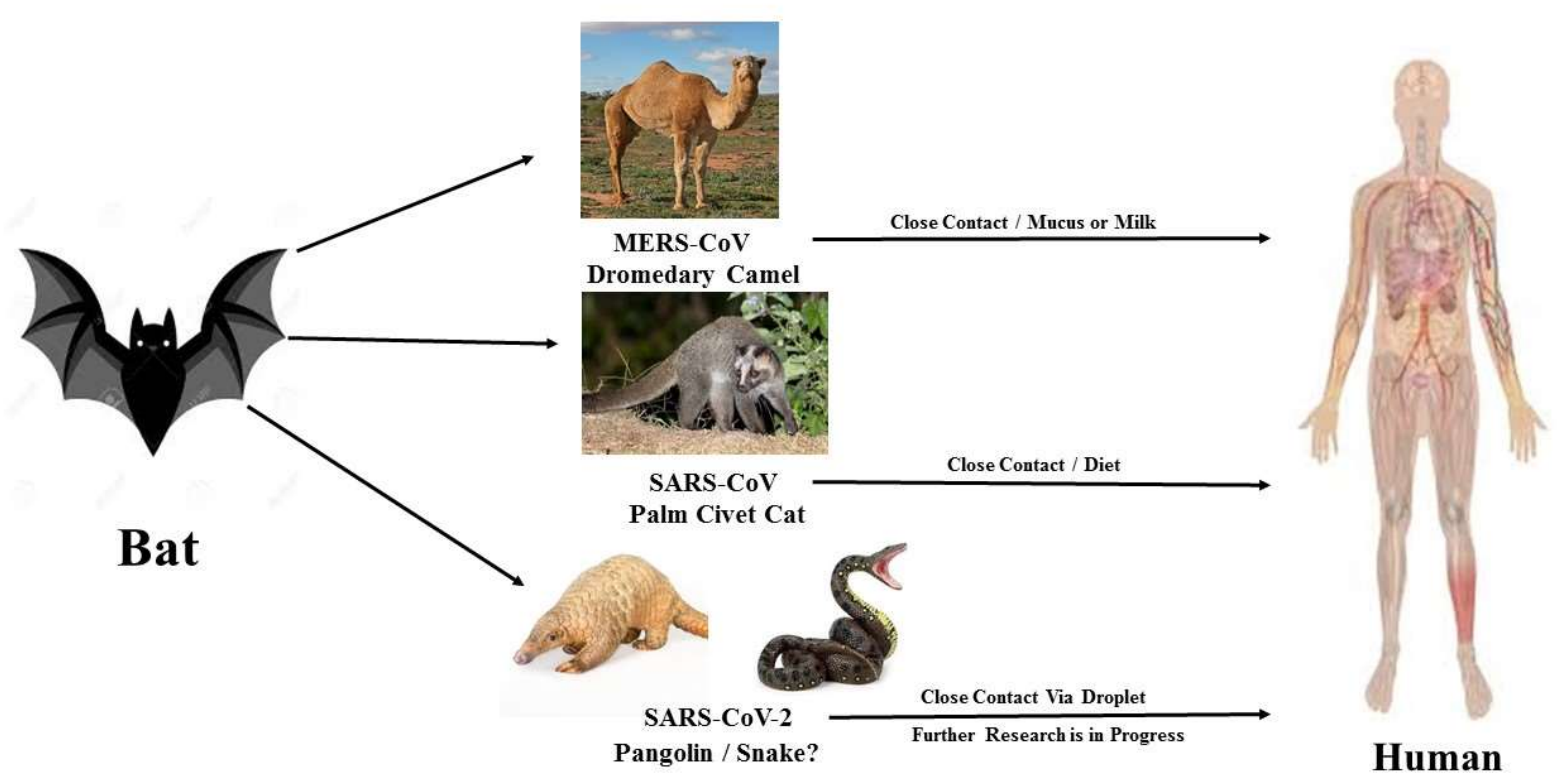

Figure 4. Diagrammatically comparison of MERS-CoV, SARS-CoV-1 and SARS-CoV-2 transmission and their possible intermediate host.

Table 3: Comparison of COVID-19, SARS and MERS in different aspects. (Chen et al., 2020b; Elengoe, 2020; Hindson, 2020; Paules et al., 2020; Raj et al., 2013; Van Doremalen et al., 2020; Walls et al., 2020; Worldometer, 2020a; Yu et al., 2004)

\begin{tabular}{|c|c|c|c|}
\hline $\begin{array}{l}\text { Diseases Name } \\
\text { Features }\end{array}$ & COVID-2019 & SARS & MERS \\
\hline Causative Agent & SARS-CoV-2 & SARS-CoV-1 & MERS-CoV \\
\hline Coronavirinae Genera & $\beta-\mathrm{CoV}$, lineage $\mathrm{B}$ & $\beta-\mathrm{CoV}$, lineage $\mathrm{C}$ & $\beta-\mathrm{CoV}$, lineage $\mathrm{B}$ \\
\hline Virus Type & RNA Virus & RNA Virus & RNA Virus \\
\hline $\begin{array}{l}\text { Entry Receptor in } \\
\text { humans }\end{array}$ & ACE2 & ACE2 & DPP4 \\
\hline Discovery Year & 2019 & 2003 & 2012 \\
\hline Origin of outbreak & $\begin{array}{l}\text { Wuhan Hubei } \\
\text { Province, China }\end{array}$ & $\begin{array}{c}\text { Guangdong } \\
\text { Province, China }\end{array}$ & Saudi Arabia \\
\hline Latency & $\begin{array}{l}\text { 2-14 days } \\
\text { (recent data show }\end{array}$ & 2-7 days & 2-14 days \\
\hline
\end{tabular}




\begin{tabular}{|c|c|c|c|}
\hline & up to 27 days) & & \\
\hline Major Symptoms & $\begin{array}{c}\text { Fever, Malaise, } \\
\text { Myalgia or Fatigue, } \\
\text { Dry cough, } \\
\text { Shortness of } \\
\text { breath, Headache, } \\
\text { RDS, Pneumonia, } \\
\text { Bilateral ground } \\
\text { glass opacities on } \\
\text { chest CT scans }\end{array}$ & $\begin{array}{l}\text { Fever, Shivering, } \\
\text { Muscle pain, } \\
\text { Lethargy, } \\
\text { Shortness of } \\
\text { breathing, } \\
\text { Cough, Sore } \\
\text { throat, Headache, } \\
\text { Diarrhea, }\end{array}$ & $\begin{array}{l}\text { Fever, shortness of } \\
\text { breath, cough, } \\
\text { nausea, vomiting, } \\
\text { and diarrhea. }\end{array}$ \\
\hline Transmission & $\begin{array}{l}\text { Exact dynamics yet } \\
\text { to be determined. } \\
\text { Possibility from } \\
\text { respiratory droplet } \\
\text { from cough or } \\
\text { sneezing; } \\
\text { Person to person } \\
\text { contact. } \\
\text { Direct contact; } \\
\text { Possibly fecal, oral, } \\
\text { nosocomial }\end{array}$ & $\begin{array}{l}\text { Person to person } \\
\text { contact. } \\
\text { Respiratory } \\
\text { droplet produce } \\
\text { due to cough and } \\
\text { sneezing, fecal } \\
\text { oral, aerosol. }\end{array}$ & $\begin{array}{c}\text { Respiratory } \\
\text { secretions such as } \\
\text { through coughing; } \\
\text { Nosocomial, } \\
\text { Close contact with } \\
\text { diseased } \\
\text { patients/camels. } \\
\text { Ingestion of camel } \\
\text { milk }\end{array}$ \\
\hline $\begin{array}{l}\text { Susceptibility to } \\
\text { Pre-existing Conditions }\end{array}$ & $\begin{array}{l}\text { Chronic respiratory } \\
\text { disease, Diabetes, } \\
\text { Hypertension, } \\
\text { Cardiovascular } \\
\text { disease, Cancer }\end{array}$ & $\begin{array}{l}\text { Diabetes, Cancer, } \\
\text { Chronic liver } \\
\text { disease, Ischemic } \\
\text { heart disease, } \\
\text { Chronic renal } \\
\text { failure, Asthma, } \\
\text { Cerebrovascular } \\
\text { disease, }\end{array}$ & $\begin{array}{l}\text { Diabetes, Cancer, } \\
\text { Chronic lungs } \\
\text { diseases, Chronic } \\
\text { heart diseases, } \\
\text { Chronic kidney } \\
\text { disease }\end{array}$ \\
\hline $\begin{array}{l}\text { Total Cases } \\
\text { (Deaths) } \\
\text { until July 10th, } 2020\end{array}$ & $\begin{array}{c}12,387,826 \\
(557,407)\end{array}$ & $\begin{array}{l}8096 \\
(774)\end{array}$ & $\begin{array}{l}2499 \\
(861)\end{array}$ \\
\hline Mortality rate & About $7 \%$ & $9.6 \%$ & $34.4 \%$ \\
\hline Countries Affected & 215 & 29 & 27 \\
\hline Reservoir & Bats & Bats & Bats \\
\hline Possible Animals hosts & $\begin{array}{l}\text { Bats, Pangolin, } \\
\text { snakes but still } \\
\text { exact reservoir host } \\
\text { is not known }\end{array}$ & $\begin{array}{l}\text { Bats, Palm civet } \\
\text { cats }\end{array}$ & Dromedary camels \\
\hline
\end{tabular}




\section{Variability and Receptor-Binding Genes in SARS-CoVs}

SARS-1 and SARS-2 both have identical genomic sequences (Song et al., 2005; Zhou et al., 2020a; Zhou et al., 2020b). Indeed, 94.6 percent of the amino-acid sequence in SARS-2 is alike to that of SARS-1 (Zhou et al., 2020a; Zhou et al., 2020b). SARS-CoV-2 was matched by a small area of RNA-dependent RNA polymerase (RdDp) from a bat CoV (BatCoVRaTG13), formerly discovered in Rhinolophus affinis from Yunnan province (Zhou et al., 2020a).

Though, in SARS, two genes (S and ORF8) showed major differences. S surface protein is composed of 2 functional subunits, S1 and S2, which are accountable for receptor attachment and cellular membrane binding, respectively (Cui et al., 2019). The S1 protein has three carboxyterminal domains and an amino(N)-terminal domain (S1-NTD) (i.e. S1-CTD1, S1-CTD2, S1CTD3) (Gui et al., 2017). The S1-CTD1 acts as a RBD for host cells (He et al., 2020), which is responsible for the attachment of ACE2 to eukaryotic cells and the entrance of SARS-2 (Huang et al., 2020c; Kuhn et al., 2004). S2 is involved in the membrane fusion (Huang et al., 2020c).

The major differences in the S gene sequence of SARS-2 compared to SARS- 1 are three short insertions in the NTD and shifts in four out of five primary residues in the receptor-attachment motif. Despite this, the close phylogenetic association with RaTG13 suggested that SARS-2 originated in bats (Zhou et al., 2020a; Zhou et al., 2020b). Orf8 protein is divided into orf8a and orf8b (Chinese, 2004). In Vero E6 cells, the Orf8a protein is non-essential for SARS-1 copying, but it may shows a part in controlling apoptosis, ER stress, and interferon responses inhibition in host cells (Hu et al., 2017).

\section{Mechanism of SARS-CoV-2 Attachment and Entry}

CoVs glycoproteins (CoVs S) are the primary target of antibodies and assist in cell entry. SARS-CoV-2 S does use ACE2 to pass in the cells, and it is of the great value that the RBDs of SARS-CoV-2 S and SARS-1 S bind to human ACE2 with comparable attractions, which explains SARS-2's rapid spread among humans (Walls et al., 2020). SARS-CoVs have a binding receptor called ACE2, while MERS-CoVs have a binding receptor called DPP4 (Du et al., 2013b; Raj et al., 2013).

CoVs use $\mathrm{S}$ on the $\mathrm{CoV}$ envelope to bind to the host cell and facilitate host cell membrane and viral membrane combination in infection (Li, 2016). Similarly, SARS-CoVs S1CTD and MERS-CoV S1-CTD act as viral RBDs (Du et al., 2013b; Raj et al., 2013). SARSCoV-2 uses Chinese horseshoe bat, human, and civet ACE2 proteins as entry receptors in ACE2expressing cells (Zhou et al., 2020a; Zhou et al., 2020b).

SARS-1 and SARS-2 bind to the human host through the RBD (S1-CTD1) protein, which binds to ACE2 ( $\mathrm{Li}$ et al., 2003; Song et al., 2018). The virus is then absorbed by the human cell through the endocytosis process (Boopathi et al., 2020). SARS-CoV-2 uses a three-step method for membrane synthesis once in the cytoplasm, starting with receptor binding and inducing conformational variations in S glycoprotein, accompanied by cathepsin $\mathrm{L}$ proteolysis by intracellular proteases and initiation of the membrane fusion mechanism within endosomes 
(Boopathi et al., 2020; Simmons et al., 2005). The endosome then unwraps, releasing the virus units into the cytoplasm, and proteasomes begin un-coating the viral nucleocapsid $(\mathrm{N})$, which can hydrolyze endogenous protein but can also degrade exogenous protein like the SARS nucleocapsid protein (Wang et al., 2010). The viral genetic material, ssRNA, is completely released into the cytoplasm, where it is activated by the replication/transcription complex (RTC) (Van Hemert et al., 2008). The viral genome encodes this complex, which is prepared up of nonstructural proteins (Boopathi et al., 2020). The RTC is thought to facilitate the development of many membrane structures in infected cells' cytoplasm (Van Hemert et al., 2008). The +ve RNA genome is encoded into ORF $1 \mathrm{a} / \mathrm{b}$ replicase proteins, which use it as a guide to generate fulllength -ve sense RNAs, which are then used to generate more full-length genomes (Boopathi et al., 2020). M, S, and E, the structural viral proteins, are made in the cytoplasm, then injected into the ER, and moved to the ER-Golgi intermediate compartment (ERGIC) (Masters, 2006; Song et al., 2004). As a result of the encapsidation of replicated genomes, nucleocapsid are formed in the cytoplasm and coalesce inside the ERGIC membrane to self-assemble into new virions (Masters, 2006). In conclusion, infected cells utilize smooth-walled vesicles to transport new virions to the cell surface, which are then secreted by exocytosis so that they can pollute additional cells (Boopathi et al., 2020). The pathway of the viral replication is shown in Figure 5.

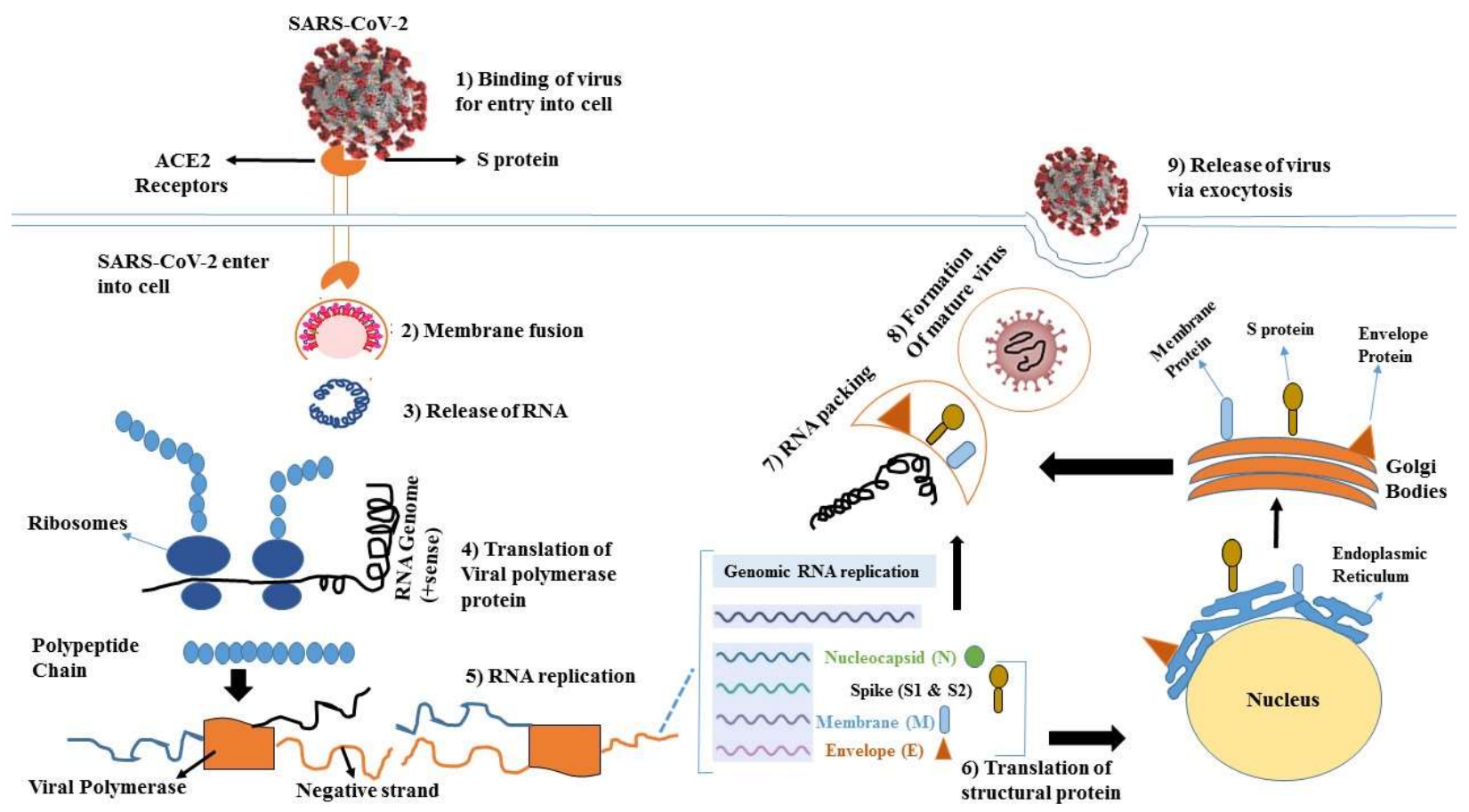

Figure 5. Molecular mechanism of SARS-CoV-2 replication in the host cell.

(Boopathi et al., 2020) 


\section{COVID-19 and the intriguing SARS-CoV-2 D614G Mutation: shall we expect others?}

According to Korber, SARS-CoV-2 changes much more slowly than the human immunodeficiency virus (HIV) as it spreads. However, Korber found a mutation in the gene encoding $\mathrm{S}$ protein (which aids virus particle penetration). Korber discovered the mutation in COVID-19 patients' samples on several occasions. The amino acid aspartates (D, in biochemical short hand) was frequently substituted by glycine (G, in biochemical shorthand) at the 614th amino-acid position of S protein due to a replication error that modified a single nucleotide in the virus's 29,903-letter RNA code. Scientists entitled it the D614G mutation (Korber et al., 2020) (Callaway, 2020).

These claims, however, alarmed many scientists, and word quickly spread through the media. It was uncertain if the D614G viral lineage was more infectious or whether its growth meant something odd. Despite the fact that several news reports contained cautionary statements from experts, the virus was altering to develop even more lethal. Montefiori and his coworkers later expressed regret for labeling the variant's growth as "alarming" (Kumar et al., 2016). D614G has ignited a whirlwind of interest as a result of the work. And those who doubted that the alteration had altered the virus's possessions finally concluded that its meteoric rise and ubiquity made it fascinating. The D614G viral lineage has been present in almost all SARSCoV-2 samples sequenced for months (see 'Global spread'). As a result of the global spread of this version, which resulted in a pandemic, its properties are significant (Grubaugh et al., 2020).

It's essential to mention that the SARS-2 virus displays a relatively high rate of mutations, questioning whether the current therapies, including a same vaccination, will be proficient and safe to other viral forms and disease characteristics.

\section{Susceptibility of domestic animals and humans to SARS-CoV-2}

SARS-2 is known to have originated in bats. The intermediate animal source of this viral infection, on the other hand, is unknown. The vulnerability of ferrets and other animals in adjacent by interaction with humans to SARS-2 was investigated in a study conducted at Harbin Veterinary Research Institute CAAS in China (Shi et al., 2020a). This study discovered that although this virus imitates poorly in chickens, pigs, dogs and ducks, it is susceptible to infection in ferrets and cats, and that cats are vulnerable to airborne infection in experiments (Shi et al., 2020a).

In 2019, SARS-2 was defined as a new pathogen, infecting people of older age (especially $>60$ years old), and people with comorbidities were defined as the highest risk for serious COVID-19 (Chen et al., 2020b; Nikolich-Zugich et al., 2020). COVID-19 made older people more vulnerable than younger people, raising their morbidity and mortality risk (Wang et al., 2020b; Yi et al., 2020). Infections in the elderly often present atypically, making diagnosis and treatment difficult. Physiologic improvements associated with ageing, as well as numerous age-related comorbid situations such as dementia, diabetes, lung and heart disease, and all lead to poor health outcomes (Nikolich-Zugich et al., 2020). SARS-CoV-2 has also been revealed to bind to ACE2-positive cholangiocytes, that could result liver dysfunction in COVID-19 infected 
individuals (Chai et al., 2020). Obesity, like type-2 diabetes, is a major threat for COVID-19 death (T2D) (Stefan et al., 2020). Obesity can lead to and diabetes, chronic kidney disease and cardiovascular disease, making patients more susceptible to cytokine storms (Kulcsar et al., 2019). Since pericytes express ACE2 at far higher levels than surrounding cells, obesity and diabetes will increase SARS-2's ability to infect surrounding pericytes by causing the endothelium of the microvasculature to leak (Mueller et al., 2020). In the United States, patients aged 65 and up account for $80 \%$ of deaths, with patients aged 85 and up suffering an overwhelming amount of serious results, like to what have occurred in China (Nikolich-Zugich et al., 2020). Adults over 65 accounted for $80 \%$ of hospital stays and had a 23 -fold higher mortality rate than those under 65 (Mueller et al., 2020). As a consequence, it is important to remember that age and underlying diseases are closely linked and can interact (Wang et al., 2004).

\section{Transmissibility}

The Huwan/Huanan Seafood Wholesale Market was connected to the majority of the early cases, and the patients may have been contaminated by zoonotic, human-to-human, and/or environmental interactions ( $\mathrm{Li}$ et al., 2020b). In SARS-1 and MERS diseases, the transmissibility of most cases occurred by nosocomial spreading (Chowell et al., 2015). It is worth seeing that SARS-1 virus emerged from the live animal's market in China and could quickly spread globally via commercial air travel (Findlater and Bogoch, 2018; Poutanen et al., 2003). Air travel can quickly link any two places of the world and has the potential to rapidly cause a pandemic. Importantly, human movement is a primary driving force pushing infection into previously nonendemic settings (Findlater and Bogoch, 2018). For instance, SARS-1 virus emerged from South China and was spread via air travel into 29 countries, causing a local epidemic in Hong Kong, Taiwan, Canada, Singapore, Vietnam, and the Philippines (Christian et al., 2004).

Similarly, since September 2012, over 2000 cases of MERS were found in 27 countries (WHO, 2019; Xu et al., 2019). South Korea was the country which suffered the most during the epidemic outside of Saudi Arabia, which was begun by a single case diseased business traveler returning from that country (Hu et al., 2015). This one case at one hospital spread to another 184 people in 17 hospitals. It was then stated that bats feces was an important source of MERSCoVs spillover (Hu et al., 2015). The direct interaction among the receiver host prone tissue and bat feces or polluted fomites became the vital connection for spreading (Wong et al., 2019). COVID-19 has reached about 215 countries within 5 months and all provinces from China was contaminated within 3 months (Worldometer, 2020a). Direct contact, aerosol (Deng and Peng, 2020), fomite, and nosocomial transmission was also involved in the transmission of SARS-2 virus (Chan et al., 2020). SARS-2 RNA was detected in fecal samples of a patient in USA (Holshue et al., 2020). Forthcoming study on the probability of SARS-2 fecal-oral spread would contain environmental studies to assess if the virus can survive in situations conducive to transmission. According to (Yeo et al., 2020), Enteric interaction and viral defecation of SARS-2 in faeces are required to see whether faecal concentrations of SARS-2 RNA relate (or not) with the nature of the disease and gastrointestinal symptoms, and (ii) faecal SARS-2 RNA can be identified during the development or recuperation stages of COVID-19. The transmission cycle from natural reservoirs to final host was given in Figure 2. 


\section{Clinical signs and symptoms in humans}

The incubation time of SARS-2 after exposure is around 1-14 days, The National Health Commission (NHC) of China implemented the "Diagnosis \& Treatment Scheme for Novel CoV Pneumonia (Trial) 6th Edition" on February 19th 2020, but later in some clinical cases the incubation duration may be as long as 27 days (range [2-27] days) (Technology, 2020). The COVID-19 patients show clinical signs and symptoms similar to H1N1 flu Influenza-like illness and pneumonia-like disease (Table 3), which include fever, malaise, myalgia or fatigue, dry cough, lymphopenia, shortness of breath, headache, hemoptysis, respiratory distress, leucopenia, pneumonia invasive lesion on lungs and bilateral ground-glass opacities on chest CT scans (Huang et al., 2020a; Hui et al., 2020). Half of the infected individuals experienced difficulty in breathing within in 7 days of infection, and serious cases quickly advanced to acute RDS, septic shock, metabolic acidosis, and coagulation dysfunction (Deng and Peng, 2020). Severe conditions can lead to respiratory problems due to alveolar injury and even death (Zhou et al., 2020a; Zhou et al., 2020b). Although some infected persons had symptoms that are close to SARS-1 and MERS, COVID-19 (positive) patients had respiratory signs and symptoms such as rhinorrhea, sore throat, or sneezing, as well as chest CT scan findings such as bilateral grounded glass opacities, representing that the target cell could be present in the lower airway (Huang et al., 2020a). Furthermore, intestinal signs and symptoms such as diarrhea were exceptional in COVID-19 patients (Chen et al., 2020a; Huang et al., 2020a; Wang et al., 2020b). In SARS-1 and MERS diseases, about 20-25\% of patients presented diarrhea (Assiri et al., 2013). The most usual symptoms of COVID-19 are acute respiratory and alveolar pneumonia, but it may also disturb the kidney, heart, digestive tract, blood, and nervous system (Wang et al., 2020b). Malnutrition caused significant loss of skeletal muscle mass and functions during prolonged ICU stays, resulting in injury, reduced quality of life, and additional morbidity (Barazzoni et al., 2020). Surprisingly, clinical settings accounted for about $25 \%$ of acute kidney injury (AKI) (Yang et al., 2020a; Zhou et al., 2020a). SARS-2 infection begins with the secretion of a high level of T-helper-2 (Th2) cytokines (e.g, IL4, \& IL10), which overwhelm swelling, unlike SARS-1 infection (Huang et al., 2020a). Furthermore, studies have revealed that extreme SARS2 patients have advanced serum concentrations of IL6, IL2, and IFN- than moderate cases, indicating that the severity of the cytokine storm is related to the severity of the disease (Liu et al., 2020a). It's also worth noting that some COVID-19 patients have no symptoms (asymptomatic population), others are asymptomatic but have "happy hypoxia" on pulmonary radiography, and severe cases of COVID-19 patients have trouble breathing due to weakened lungs, even at an initial stage of the disease. Current imaging of a hypoxic patient revealed "almost waxy-looking film everywhere the lungs," and several of them had pulmonary lesions on radiography photos, among other things. Clotting is now recognized by many doctors as a significant characteristic of extreme COVID-19. As a result, Negri, a Brazilian doctor from USP, Brazil, speculated that subtle clotting could start first in the lungs, likely due to an inflammatory response in their fine network of blood vessels, which might activate a cascade of proteins that causes blood to clot and averts it from receiving enough oxygen (Negri et al., 2020). Negri came up with this definition after treating a woman who had respiratory issues as well as circulatory problems in her toes. The woman's toes and breathing also improved after Negri's team gave her heparin, a common blood thinner. If clotting induces happy hypoxia, "it is actually unknown" (Couzin-Frankel, 2020). 


\section{Diagnosis}

COVID-19 is diagnosed using clinical recommendations recommended by the People's Republic of China's, NHC and the National/State Administration of Traditional Chinese Medicine (NATCM) (TCM) (Deng and Peng, 2020). Concerns about travel history, direct contact with positive patients, CT imaging, molecular bioassays (such as RT-PCR), serological and biochemical tests (as well as renal and liver function, creatine kinase (CK), lactate dehydrogenase (LDH), and electrolytes/ ionogram) were among the early inquiries. Respiratory samples such as pharyngeal and nasal swabs, bronchial aspirates, bronchoalveolar lavage fluid, and sputum were screened for common viruses such as avian influenza, influenza, SARS-CoVs, and MERS-CoVs using a RT-PCR assay (Huang et al., 2020a).

\subsection{CT Imaging}

Chest CT is a traditional, non-invasive imaging method with great precision and speed that is critical in the fight against COVID-19. Indeed, chest CT can detect early stages of lung infection, prompting more extensive public health surveillance and response systems (Kanne, 2020; Pan et al., 2020). As a result, approximately $60 \%$ of COVID-19 patients had normal CT characteristics (e.g., varying grades of ground glass opacities with/without crazy concrete sign, multifocal organizing pneumonia, and architectural alteration in a marginal dissemination) even before the disease's positivity was reported by RT-PCR (Ai et al., 2020). This means that CT imaging can be extremely convenient for early finding of suspicious cases (Huang et al., 2020b; Lei et al., 2020; Pan et al., 2020). Actually, chest CT results of viral pneumonia were accepted as indication of a COVID-19 infection clinical diagnosis. Though, the WHO will not accept CT without RT-PCR validation till February 17, 2020 (WHO, 2020a; Zu et al., 2020).

\subsection{Real-Time PCR/Quantitative PCR and Conventional PCR}

PCR is the gold standard test to detect pathogens. It is a rapid, simple, cost-effective, very sensitive and specific routine technique (Mackay, 2004), (even if few false positives and false negatives may occur). Both quantitative PCR ( $\mathrm{qPCR}$ ) and conventional PCR are used for the finding of COVID-19. In a brief, RNA is mined from a throat swab and examined using realtime RT-qPCR with SARS-2 unique primers and probes (Poon et al., 2005; Zhou et al., 2020a; Zhou et al., 2020b). Premier pairs were designed from the 2019-nCoV S gene for qPCR research; while traditional PCR was performed using the following premier pairs (Poon et al., 2005; Zhou et al., 2020a; Zhou et al., 2020b).

ND-CoVs-951F 5'-TGTKAGRTTYCCTAAYATTAC-3'

ND-CoVs-1805R 5'-ACATCYTGATANARAACAGC-3' 
If two targets (e.g., ORF1a, ORF1b, gene encoding the nucleocapsid protein) were verified by real-time RT-qPCR, then the patient was a confirmed SARS-CoV-2 positive case (Li et al., 2020c).

\subsection{Viral Genome Sequencing}

The genome was cloned and sequenced using RNA derived from respiratory system fluids. The viral genome was discovered using a combination of Illumina sequencing and Nano-spore sequencing. Specific primers were designed to seal genome gaps from conventional Sanger sequencing. Multiple sequence alignment and reference sequences for SARS-CoV-2 were done using Multiple Sequence Comparison by Log-Expectation (MUSCLE) software (e.g., https://www.ebi.ac.uk/Tools/msa/muscle/). The whole-genome phylogenetic analysis was done with RAxML computer program (e.g. https://cme.hits.org/exelixis/web/software/raxml/hands on.html) with 1000 bootstrap replicates (Zhu et al., 2020).

\subsection{Electron Microscopy}

Electron microscopy is a valuable instrument in the field of microbiology. It has been important in the quick detection of viruses in patient samples, as well as in the clarification of virus structure and function, assisting public health in combating emerging viral infections. The infection S cycle of SARS-2 in Vero E6 cells was studied using scanning electron microscopy (SEM) (Brahim Belhaouari et al., 2020). Virus morphology is usually examined using electron microscopy (Zhou et al., 2020a) After inoculation, light microscopy and transmission electron microscopy were used to analyze virus particles in 2019-nCoV-infected human airway epithelial cells, 2019-nCoV-infected human airway epithelial cultures and mock-infected human airway epithelial cells (Zhu et al., 2020).

\subsection{Antigenic Tests}

The extraordinary situation has ignited global concern. The development of highly detailed procedures for the quick credentials and separation of SARS-CoV-2 patients is a critical policy for dealing with the COVID-19 pandemic. As a result, several companies and research institutions are working to establish successful approaches for the quick identification of SARSCoV-2 ribonucleic acid (RNA), antigens, antibodies and the virus (Ji et al., 2020a).

The SARS-CoV-2 antigen test is a diagnostic test designed to rapidly recognize viral proteins (antigens). While the speed at which these antigen tests are conducted is their primary advantage, they are frequently overwhelmed by incorrect results and have poorer compassion and specificity than nucleic acid amplification tests (NAAT). For influenza (H1N1) and respiratory syncytial virus, RT-PCR was found to be more susceptible than previous rapid antigen studies (Chartrand et al., 2015). Antibodies precise to viral antigens are frequently challenging and time taking to produce, and antigen studies must adhere to strict quality control protocols to confirm specificity and sensitivity. Though antigen tests are accurate for the virus, they do not sense all active infections and therefore have a developed false negative rate than 
RT-PCR. The Sofia 2 SARS Antigen FIA test, which uses immunofluorescence-based lateral flow machinery in a sandwich configuration to detect the viral nucleocapsid protein in nasopharyngeal and nasal swab specimens and provides results in 15 minutes, was granted an EUA by the FDA (Chau et al., 2020). COVID-19 Ag Respi-Strip (Coris Bioconcept, Gembloux, Belgium) is a ready-to-use test that detects SARS in a rapid and qualitative manner. The involvement of CoV-2 antigen in nasopharyngeal discharges (Scohy et al., 2020). Centered on membrane technology with colloidal gold nanoparticles (AuNPs), this test employs monoclonal antibodies to detect the extremely conserved SARS-CoV and SARS-CoV-2 nucleoprotein antigens. A monoclonal antibody is also conjugated to colloidal AuNPs. These antibodies bind to the nitrocellulose membrane and become immobilized. The test was carried out in accordance with the manufacturer's instructions, by combining 100L of nasopharyngeal discharges with 4 drops (approximately 100L) of LY-S dilution buffer in a tube and adding the strip. Passive diffusion allows the solubilized conjugate to migrate with the sample and react with the antiSARSCoV-2 antibodies immobilized on the membrane when the nasopharyngeal discharges interact with the strip. A control line is used in the strip to ensure that the sample migrates correctly. After 15 minutes, the result is visually read. The test was evaluated in two versions. The conjugate was coupled differently in the second edition, and the control line was optimized (Scohy et al., 2020).

Future work on the clinical presentation of antigen testing versus NAAT is strongly cheered in order to determine their diagnostic utility (Chau et al., 2020).

\section{Treatment}

The treatment of COVID-19 is broadly divided into two categories: the managerial treatment and the medicinal treatment.

\subsection{Managerial Treatment.}

Suspected and confirmed cases need successful isolation and security measures (Jin et al., 2020). Asymptomatic cases but in closed contact with COVID-19 patients must be diagnosed. Patients with flu- or pneumonia-like symptoms should be managed properly to avoid confounding flu symptoms with COVID-19. Alleged cases would be quarantined in a solitary room until verified. Verified cases could be put in a separate room from suspected cases, or they could be placed in the same room as suspected cases. Sensitive cases, on the other hand, must be handled in the ICU as soon as possible. Routine checkup of blood, urine (to assess levels of liver and myocardial enzymes, renal function parameters, coagulation factors etc) as well as respiratory support (e.g. noninvasive mechanical ventilation, intubation, tracheostomy) should be done if needed (Jin et al., 2020). For patients suffering from extreme respiratory infections, RDS, hypoxemia, or shock, oxygen therapy is the treatment of choice (Jin et al., 2020). For persons with refractory hypoxemia that is challenging to treat with caring lung ventilation, extracorporeal membrane oxygenation (ECMO) should be considered (Jin et al., 2020). All critically ill patients should be given bed rest, though nutritional and supportive therapy, such as blood pressure and oxygenation, are vital steps. Other steps include preventing and treating complications, maintaining hemodynamic stability, and preventing secondary infection (Naicker et al., 2020). 
Tracheostomy is used in the critically ill patients, and early tracheostomy has been associated with reductions in the duration of mechanical ventilation (Michetti et al., 2020). Therefore, a multidisciplinary team (e.g. infectiologists, urgentists/intensive care specialists, internists, hematologists, cardiologists, radiologists, general surgeons, allergologists, dermatologists, gastroenterologists, neurologists, pharmacists, microbiologists, nurses, and psychologists) must be involved during the stay of the COVID-19. Social distance avoiding direct/close human contacts, washing of hands, wearing appropriate masks models (i.e., FFP2, FFP3), and the use of approved hand sanitizer products, participate to the prevention of the disease. It is worth noting that FDA has warned consumers and healthcare providers against ingestion of hand sanitizer product contaminated with methanol (although increasingly labeled as containing "Ethanol") that has headed to current hostile events as well as blindness, hospitalization and demise (FDA, 2020).

\subsection{Medicinal Treatment}

Drug repurposing is an efficient method of rapidly identifying a therapeutic drug with a known safety profile to treat a new disease. Currently there is no clear and appropriate treatment for COVID-19 that has been approved by the world's highest authorities. Therefore, finding the proper antiviral drug or drug regimen (e.g., chemotherapeutic/biotherapeutic, and/or immunotherapeutic/vaccinotherapy) against this disease is urgently required.

The treatment of the COVID-19, especially in an exhaustive care setting, usually includes (i) antiviral therapy (e.g. Azythromycin) (Bleyzac et al., 2020); (ii) broad-spectrum antimicrobials (e.g. Meropenem, Ciprofloxacin, Levofloxacin, Ceftriaxone, Fungizone) to treat bacterial and fungal co-infections (Cox et al., 2020), and reduce chances of secondary bacterial infections, mostly pneumonia (e.g. induced y P. aeruginosa and $S$. aureus) and chronic diarrhea (e.g. induced by Clostridium difficile) (Manohar et al., 2020); (iii) supportive therapies (Phan et al., 2020); (iv) ECMO (e.g. personalized oxygen therapy methods) (Chen et al., 2020b; Holshue et al., 2020); (v) anticoagulants (e.g. LMW heparin) (Kow and Hasan, 2020); (vi) Corticosteroid therapy (e.g. high dose methylprednisolone, 40-120 mg per day) and oxygen support (e.g. nasal cannula, and invasive mechanical ventilation) (Huang et al., 2020a).

The current COVID-19 can be alienated into three stages. stage I, an asymptomatic incubation phase (average duration of 14 days); stage II, a non-serious yet symptomatic period with virus presence (average duration of 7-8 days); and stage III, a severe respiratory symptomatic stage (over a week) that can be lethal if not handled, well controlled, or if the patent has multiple comorbidities/risk factors (Shi et al., 2020b).

Therefore, the managerial treatment and the medicinal treatment differ. To date, it has been shown by Raoult's French team that the first phase of COVID-19 would be managed better with a combination of Azithromycin and hydroxychloroquine (Gautret et al., 2020).

\subsubsection{Use of anti-viral drugs against COVID-19.}

Initial phases of the COVID-19-induced pneumonia epidemic, antiviral drugs (oseltamivir orally $75 \mathrm{mg}$ twice a day) were administered on a trial basis. (Huang et al., 2020a). Lopinavir and 
Ritonavir were found to be effective in a previous outbreak of SARS-1 disease, with few adverse clinical outcomes (Chu et al., 2004). Interferon beta-1b, ritonavir and lopinavir, were effective against SARS-CoVs and MERS-CoVs in a placebo-controlled trial (Hung et al., 2020). In-vitro and in-vivo (animal) studies indicated that the combination of Interferon-1b, Ropinavir, and Ritonavir is operative against MERS-CoV (Arabi et al., 2018). Remdesivir has been revealed to be in effect in treating MERS-CoV and SARS-CoV-2 infections in preclinical studies (Sheahan et al., 2017; Sheahan et al., 2020). Ribavirin, Lopinavir, Interferon, corticosteroids and Ritonavir were used during the previous SARS epidemic, but their effectiveness remains debatable. As a result, a randomized controlled trial was conducted to evaluate the effectiveness and protection of combining Ritonavir and Lopinavir in persons hospitalized with COVID-19 infection (Huang et al., 2020a). However, these treatments were not always useful in COVID-19 cases. Also, the cases of Remdesivir raise some controversies. Indeed, although a ten-day course of Remdesivir therapy (200 mg dose I/V on first day, tracked by $100 \mathrm{mg}$ every day for continuing 9 days of treatment) prescribed to a group of serious hospitalized COVID-19 patients resulted in clinical enhancement in 36 of 53 diseased people (68 percent), it was argued that the estimation of efficacy may be skewed due to the study's limited follow-up, small cohort population, and lack of a randomized, placebo-controlled trial (Grein et al., 2020). Intriguingly, Ivermectin, an FDAapproved anti-parasitic drug, was revealed to have wide spectrum antiviral property in vitro, including the ability to reduce 5000-fold the viral RNA load of SARS-CoV-2 in 48 hours when added to Vero-hSLAM cells 2-hours after infection (Caly et al., 2020). Remdesivir, a nucleotide analogue pro-drug that reduces viral RNA polymerases, has demonstrated anti-SARS-CoV-2 activity in vitro (Grein et al., 2020).

\subsubsection{Use of antibiotics against COVID-19.}

In the rise of the SARS-2-induced pneumonia cases during early stages, antibiotics (orally and intravenously administrated at usual dose of 500 to $1000 \mathrm{mg} /$ day depending on individual's weight) were empirically given (Huang et al., 2020a). Teicoplanin, a glycopeptide antibiotic widely castoff to treat staph infections, has previously demonstrated effectiveness in inhibiting the initial stage of the MERS viral cycle in human cell (Baron et al., 2020). This activity was conserved against SARS-2, implying that teicoplanin could be used as an anti-viral agent (Baron et al., 2020). According to another study, teicoplanin acts early in the CoVs life cycle by preventing the low $\mathrm{pH}$-sensitive cleavage of the viral $\mathrm{S}$ protein by cathepsin $\mathrm{L}$ in late endosomes, preventing the discharge of genomic viral RNA and the continuation of the virus replication cycle (Zhang et al., 2020). According to a current study, this behavior is conserved on SARS-2; in fact, the target sequence that serves as a cleavage site for cathepsin $\mathrm{L}$ is conserved among SARS-2 S protein (Zhang et al., 2020). In vitro, the concentration of teicoplanin needed to prevent 50 percent of viruses (IC50) was $1.66 \mathrm{M}$, which was much lower (about 5 folds) than the concentration reached in human blood $(8.78 \mathrm{M})$ when a daily dose of $400 \mathrm{mg}$ was administered (Zhang et al., 2020).

\subsubsection{Use of Monoclonal Antibodies against COVID-19.}

Unlike antigenic domains of the viral envelope glycoprotein are attacked by monoclonal antibodies (Xu et al., 2019). Despite the production of new mAbs to attack the RBD component 
of S glycoprotein, RBD does not appear to be a site for anti-MERS-CoV antibody responses (Xu et al., 2019). mAbs targeting the S1 NTD region, which lacks RBD, were recently isolated from S glycoprotein-immunized mice (Chen et al., 2017). In cell culture models, the antibody 5F9 effectively blocked MERS-CoV virus entry (Wang et al., 2015). Human neutralizing antibodies are essential components of protective immunity against viral infection.

Neutralizing antibodies that block COVID-19 are B38, H4, 47D11 have shown excellent results to control the novel coronavirus infection. Studies on patient who are on plasma therapy, also shows improvement (Jahanshahlu and Rezaei, 2020).

\subsubsection{Use of Chloroquine and Analogs against SARS-CoV-2: A Useless Polemic?}

Chloroquine (marketed as Plaquenil or Nivaquine), an antiprotozoal medication used to treat and prevent malaria (aka paludism) and autoimmune disorders (e.g., rheumatoid arthritis (RA), systemic lupus erythematosus (SLE), has been shown to prevent the replication of several DNA and RNA viruses, including several human CoVs (Devaux et al., 2020). At least ten experimental trials are currently testing chloroquine as an anti-COVID-19 treatment (Devaux et al., 2020; Harrison, 2020). Chloroquine was most likely the first molecule used as first-line treatment for SARS-CoV-2 infection in China and elsewhere (Devaux et al., 2020). Chloroquine remained one of the best available candidates for influencing newly emerged virus in humans, and Chinese experts suggested that patients with pneumonia, acute or austere cases of COVID-19, and no side effects to chloroquine, be treated with $500 \mathrm{mg}$ chloroquine two times a day for continuous 10 days (Millán-Oñate et al., 2020).

Chloroquine has recently been discovered to suppress SARS-CoV-2 in vitro, and its hydroxylated form (i.e. hydroxychloroquine) has been proposed as a possible treatment for SARS-CoV-2 patients (Colson et al., 2020; Wang et al., 2020c). In vitro, hydroxychloroquine (a chloroquine analogue) prevented SARS-CoV-1 replication (Biot et al., 2006). The clinical protection outline of hydroxychloroquine is inferior to that of chloroquine (over time), providing for a greater daily dose to be used if needed (Marmor et al., 2002), and is less worried about drug-drug interactions (Yao et al., 2020).

In addition, in multicenter clinical trials, chloroquine phosphate (another analogue of chloroquine) demonstrated marked effectiveness and appropriate protection in treating COVID19 related pneumonia (Gao et al., 2020).

Importantly, only Remdesivir and chloroquine repressed SARS-CoV-2 infection in Vero E6 cells, out of the seven drugs studied, namely chloroquine, Remdesivir (GS-5734), ribavirin, nafamostat, penciclovir, nitazoxanide and Favipiravir (T-750). This indicates that these drugs may be tested in human patients suffering from COVID-19 (Wang et al., 2020c). Although there was a big polemic in France and in some other few countries about the utility of hydroxychloroquine administration in patients without appropriate clinical trials beforehand the eminent researches and clinical observations made by Raoult's French team, and confirmed by a major part of clinical researchers and practitioners worldwide, demonstrated a relative good benefits/risks ratio especially when hydroxychloroquine (about 11\% efficiency) was combined to 
Azithromycin (about 27\% efficiency) during the first phase (one week duration) of COVID-19 (Gautret et al., 2020). This combination was a good step to minimize most of the patients entering in the second phase (severe) of COVID-19, since no other solution was offered at the beginning of the pandemic.

\subsubsection{Use of Traditional Chinese Medicine (TCM) against SARS-CoV-2.}

Medicinal plant is a main source of drug discovery for disease management. Over $85 \%$ of the population in Asia (and in the Middle East) use herbal medicine for disease management such as SARS caused by CoVs (Adeleye et al., 2021). Natural Products used in TCM remains original therapeutics for human diseases treatment (Cragg and Newman, 2013). The Chinese government highly valued the TCM in the eradication campaign of SARS-CoV-2. Health commission officially declared the use of TCM in 26 provinces counter to SARS-CoV-2 in along with conventional medicine (Yang et al., 2020b). Numerous Chinese herbal remedies are suggested for patients in the medical opinion, probably as a precautionary measure, according to the most recent NHC guideline version, and include: Lian Hua Qing Wen (capsule), Huo Xiang Zheng Qi Shui, Jin Hua Qing Gan and Shu Feng Jie Du (capsule) are all members of the Huo Xiang Zheng Qi Shui community (granule). During the clinical treatment time, Xi Yan Ping (injection), Qing Fei Pai Du Tang, Tan Re Qing (injection), Re Du Ning (injection), Xue Bi Jing (injection) and Xing Nao Jing (injection) are recommended (Yang et al., 2020b). Importantly, according to a National Administration of TCM survey, Qing Fei Pai Du Tang had an overall effective rate of 90\% in COVID patients from Shanxi, Hebei, Heilongjiang, and Shaanxi provinces (Yang et al., 2020b). Among them, the symptoms of the majority (60\%) were evidently enhanced, while the disease of others (30\%) was stabilized (Yang et al., 2020b). Another research showed that 18.5 percent of patients were fully healed after undergoing Qing Fei Pai Du Tang medication (Zhao et al., 2020). The procedure also lead to the vanishing of COVID-19-specific symptoms such as cough and fever in 7.27 percent of patients (Zhao et al., 2020). Furthermore, 38.2 percent and 30.2 percent of patients experienced symptoms improvement and stabilization, respectively (China, 2020b). Furthermore, clinical efficiency of Lian Hua Qing Wen (capsule) was observed during treatment of SARS-CoV-2 patients, both confirmed and suspected cases (Yang et al., 2020b). Furthermore, in a rat model of lipopolysaccharide (LPS)-induced acute lungs injury, Re $\mathrm{Du}$ Ning (injection) significantly decreased the levels of IL-1, TNF-, IL-8, IL-10, and other cytokines and interleukins (Zou et al., 2019).

Overall, the data showed that these herbal products could substantially alleviate main symptoms such as fever and cough, as well as promote recovery (Yang et al., 2020b). This highlights the relative importance of phytotherapy. Indeed, the search for medicinal plants with inhibitory bioactive compounds against $\mathrm{CoVs}$ could be a valuable supportive therapeutic option (Adeleye et al., 2021). A most recent review reported the identification of twenty medicinal plants that possess key bioactive compounds having potential activity against CoVs (Adeleye et al. 2021). It was postulated that the combination of extracts or phytochemicals from these plants could be developed into various drug delivery systems (e.g., nano carriers) in order to switch the new COVID-19 pandemic (Adeleye et al., 2021). 


\subsubsection{Convalescent Plasma (CP).}

Plasma from people improved from COVID-19 infection, particularly after severe illness, may contain high level of polyclonal, pathogen specific antibodies (Estcourt and Roberts, 2020). These antibodies may confer passive immunity to recipients, by neutralizing viral particles (Casadevall and Pirofski, 2020). Indeed, shorter hospital stay and lesser mortality rates were observed for the patients of SARS-CoV-1 treated with CP in comparison to the control group (Cheng et al., 2005). Therefore, it would be worthwhile to test the efficacy of CP taken from the recovered patients on the COVID-19 patients. Since CP has not been approved for use against COVID-19 by FDA yet, it is being regulated under the investigational product. From 23, January to 19 , February 2020, ten extreme COVID-19 patients were enrolled and received a $200 \mathrm{~mL} \mathrm{CP}$ transfusion as well as neutralizing antibody titer values greater than 1:640, in addition to standard treatment and other antiviral medications (Duan et al., 2020). Safety of CP transfusion was kept the primary endpoint, whereas the enhancement in the clinical sign and symptoms within three days of CP transfusion remained the second endpoint. Following CP transfusion, the amount of neutralizing antibody improved quickly in five cases, reaching 1:640, while it stayed elevated in the other four cases (1:640). Medical symptoms, as well as oxyhemoglobin saturation, had improved drastically within three days (Duan et al., 2020). Several parameters tended to increase lymphocytes count $\left(0.65 \times 10^{9} / \mathrm{L}\right.$ vs. $\left.0.76 \times 10^{9} / \mathrm{L}\right)$ and reduced level of Creactive protein $(55.98 \mathrm{mg} / \mathrm{L}$ vs. $18.13 \mathrm{mg} / \mathrm{L})$ with no opposing properties (Duan et al., 2020). However, there are various downsides to this approach which includes the difficulty in scaling up for widespread use as well as the risk of transmission of other diseases that would come along with the plasma of recovered patients. Also, the antibodies present in the plasma generally are in lesser concentration that may not be sufficient for the treatment.

Regeneron Company from US is about to introduce two antibodies that could act against COVID-19 which can be synthetically produced, and their clinical trial would be started later. This would be helpful as both prophylactic and as a treatment measure especially for high-risk groups (Ahsan et al., 2020).

\subsubsection{Advancements in Coronavirus Vaccine Development}

The vaccine is thought to be an effective treatment to prevent and control CoVs, albeit not so easy to develop in addition to possible associated side-effects. Indeed, over the last few years, various approaches to more than twenty vaccine candidates against CoVs have been taken, including vaccines based on inactivated virions (Agrawal et al., 2016; Deng et al., 2018), viruslike particles (Wang et al., 2017), recombinant viral vector (Jung et al., 2018; Song et al., 2013), DNA (Chi et al., 2017; Wang et al., 2015), recombinant protein subunits (Du et al., 2013a; Jiaming et al., 2017), and nanoparticles (Coleman et al., 2017; Jung et al., 2018). mAbs showed promising antiviral properties against $\mathrm{CoVs}$ infections in cell culture and animal models.

However, since the therapeutic window for mAbs is usually narrow and mass-scale creation is time and resource intensive, their roles in large-scale disease inhibition (e.g., MERS-CoVs) in high-risk areas remain restricted (Xu et al., 2019). 
Nonetheless, it is anticipated that the vaccine will continue to be the best option for $\mathrm{CoV}$ prevention and control (Xu et al., 2019). Because of their critical roles in viral access and as significant targets for neutralizing antibodies, $\mathrm{S}$ glycoprotein and RBD have emerged as the primary targets for MERS-CoVs immunogen strategy and vaccine growth (Xu et al., 2019). The majority of possible vaccine studies are in the preclinical stage, but 3 vaccine candidates, GLS5300, MERS001, and MVA-MERS-S, have reached human medical trials with mature volunteer nominees (Muthumani et al., 2015). GLS-5300 is based on a DNA plasmid (pVax1) that contains a gene sequence codes for the diverse domains of the $\mathrm{S}$ protein, as well as a sequence codes for a great efficacy immunoglobulin E leader peptide to promote RNA expression and export (Chi et al., 2017; Muthumani et al., 2015).

Researchers are trying to develop a vaccine against all CoVs, including COVID-19 and its possible variants. Like antiviral drugs, vaccine may not work to definitively control the viral infection because of the high mutation rate of CoVs, and so vaccines shall be developed to prevent against each mutant. Furthermore, there is a deficiency of immunological data on the SARS-CoV-2 virus at the moment (e.g., details on immunogenic epitopes that induce an antibody or $\mathrm{T}$ cell response).

SARS-CoV-2, like SARS-CoV-1 and MERS-CoV, is a member of the betacoronavirus genus (Lu et al., 2020c), Preliminary experiments using the whole genome and phylogenetic analysis indicated that SARS-CoV-2 is very similar to SARS-CoV-1 (Lu et al., 2020c; Zhou et al., 2020a). According to several references, SARS-CoV-2 uses the identical cell entry receptorangiotensin converting enzymes ii (ACE2) as SARS-CoV-1 (Zhou et al., 2020b). Since the two viruses (SARS-CoV-1 and SARS-CoV-2) tend to be so alike, Prior investigation that has delivered an sympathetic of defensive immune responses to SARS-CoVs could possibly be used to support in the development of SARS-CoV-2 vaccines (Ahmed et al., 2020a).

Currently, a vigorous research effort is on the move to develop the most safe and efficient vaccine against Covid-19 (WHO, 2020b). About 165 SARS-CoV-2 vaccine candidates are recently being tested round the globe, with eight of them in phase III trials and two of them, the Russian vaccine and a Chinese vaccine, approved for limited use (Mahase, 2020a). The Chinese government has granted special permission for CanSino's Ad5-nCoV vaccine to be used in the armed forces (Mahase, 2020b). The Gameleya Institute in Moscow developed the Russian vaccine, which uses 2 human adenovirus vectors and the SARS-CoV-2 spike protein to induce an immune response (Mahase, 2020a). According to the clinical trials database, the Gamaleya Institute has reported two nearly identical trials, both involving 38 individuals. The first trial employs Gam-COVID-Vac-Lyo, a "lyophilisate for the preparation of an intramuscular solution," while the second employs Gam-COVID-Vac, a COVID-19 vaccine candidate administered intramuscularly (Mahase, 2020a). SARS-CoV-2 vaccine trials are currently in progress, with researchers from the University of Oxford and AstraZeneca (AZD1222) anticipating the very first phase 3 clinical results this summer. While most infection experts agree that even 18 months for the first vaccine is too ambitious, a few idealists assume that hundreds of millions of vaccine doses will be prepared for delivery by the end of 2020 (Mullard, 2020). 
In December 2020, the FDA approved an Emergency Use Authorization (EUA) for the PfizerBioNTech COVID-19 (BNT162b2) vaccine. (Pfizer, Inc; Philadelphia, Pennsylvania) (Oliver et al., 2020), AstraZeneca-Oxford Oxford University and AstraZeneca collaborated to create the COVID-19 vaccine, codenamed AZD1222 (Wikipedia, 2020). According to a non-peerreviewed, real-world report from the United Kingdom, both the Pfizer/BioNTech and AstraZeneca/Oxford University COVID-19 vaccines substantially minimize serious disease, hospitalization, and fatalities in the older and provide safety against the B117 variant. The scientists discovered that single dose of the Pfizer vaccine has 57\% - 61\% efficacy in inhibiting symptomatic COVID 19 after fourth week, while the AstraZeneca vaccine has $60 \%-73 \%$ effectiveness. Two doses of the Pfizer vaccine were approximately 85\% - 90\% real against symptomatic illness. Since second doses of the AstraZeneca vaccine have not yet been offered in England, it is too early to determine their effectiveness (Beusekom, 2021). The Pfizer-BioNTech COVID-19 vaccine is given $\mathrm{I} / \mathrm{M}$ in 2 doses of $30 \mathrm{~g}$ and $0.3 \mathrm{~mL}$ three weeks apart.

The Advisory Committee on Immunization Practices (ACIP) released an interim statement recommending that adults over the age of 16 receive the Pfizer-BioNTech COVID-19 vaccine to defend against COVID-19 (Oliver et al., 2020). The suggested dosage is two intramuscular doses $(0.5 \mathrm{ml}$ each $)$ spaced $8-12$ weeks apart. The vaccine is not recommended for people under the age of 18 , but the results are still being studied (WHO, 2021).

The Medicines and Healthcare products Regulatory Agency in the United Kingdom has carefully reviewed the currently approved COVID-19 vaccines (the MHRA). The trial safety findings, which included numerous months of follow-up data from 23,000 individuals for the Oxford-AstraZeneca vaccine and 44,000 individuals for the Pfizer-BioNTech vaccine, were closely reviewed by the regulatory teams. This means that the MHRA has analyzed all of the evidence from these vaccines' medical trials, including assessing all of the adverse properties and medical situations that participants in the trials faced. This means that the MHRA has analyzed all of the evidence from these vaccines' clinical trials, while evaluating all of the negative impacts and medical conditions that participants in the trials faced. When a serious disease is discovered, a medical doctor involved in the patient's care and an independent safety committee determines if the infection was caused by the vaccine. Almost all negative impacts (unexpected illnesses) were identified to regulators during the trial, and the safety profiles of the OxfordAstraZeneca and Pfizer BioNTech vaccines are comparable to other vaccines (Project, 2021).

\section{Prognosis}

COVID-19, SARS-CoV-1, and MERS-CoV are all related to a high morbidity and death rate in infected individuals with serious cases. The majority of COVID-19 deaths occurred in people over the age of 50.Young children are usually only mildly infected, although they could serve as a vector for further transmission (Cascella et al., 2020). Men were contaminated with SARS-CoV-2 at a higher rate than women $(0.31 / 100,000$ vs. $0.27 / 100,000$ ) (Yang et al., 2020c). Patients above the age of 65 and those suffering from basic diseases have a poor prognosis (Deng and Peng, 2020). COVID-19 patients who need rigorous care are more probable to suffer from acute heart injury and arrhythmia (Deng and Peng, 2020). According to one Chinese meta-analysis of 1527 patients, 
hypertension (17.1 percent, 95 percent CI 9.9-24.4 percent) and cardio-cerebrovascular disorders (16.4 percent, 95 percent CI 6.6-26.1 percent) were the most common cardiovascular metabolic comorbidities with COVID-19, followed by diabetes $(9.7$ percent, 95 percent CI 6.9-12.5 percent). The infected persons with diabetes or hypertension have a two-fold rise in the probability of developing severe disease or requiring rigorous care unit admittance, while patients with cardio-cerebrovascular disease have a threefold increase (Li et al., 2020a).

\section{Prophylaxis}

Prophylaxis is an effective technique in immunocompromised patients. Since there are no known prophylactic drugs for COVID-19, population safety against coming into contact with the pathogen should be improved (Ju et al., 2020).

Following the outbreak, almost all provinces in China launched a level-1 public health reply to monitor COVID-19 (Xu et al., 2020). A level-1 response meant that under such emergence circumstances, the provincial headquarters would establish and direct the emergence response worked in its organizational areas in accordance with the state council's decision deployment and unified command (Deng and Peng, 2020). Fewer observation rooms have been set up at railway stations, airports, ports, and all other entry points of provinces and countries in order to detect passengers' body temperatures and other signs/symptoms entering and leaving the city (China, 2020a). Suspicious individuals were observed/registered, and those individuals were subjected to a PCR test to validate (or not) their positivity (Deng and Peng, 2020).

As previously mentioned, there is no vaccine available to prevent SARS-CoV-2 infection at this time. The best way to stop infection is to avoid contact with this virus. Since the virus is spread from person to person and has a high virulence, quarantine is used to prevent and regulate it. Since the incubation period can last up to 27 days on average, any person who has been exposed should be quarantined for at least 14 days under medical supervision (Li et al., 2020b; Technology, 2020).

Isolation of suspicious patients, restriction of people movement, and disinfection of the region with chlorinated water are all part of the prevention and control measures (Huang et al., 2020a). Hand washing with soap and then with hydroalcoholic gel, covering mouth and nose while coughing and sneezing, and meticulously preparing meat and eggs are all normal recommendations to avoid infection spread. Avoid contact with sick and spoil animals (including domestic cats), as well as close contact with other people (i.e., social distance), especially those who have a fever and/or respiratory illness, such as coughing and sneezing, air precaution using masks properly and adequately (i.e. fit-tested N95 (FFP2/FFP3 masks and PPE for health care setting) (WHO, 2019).

CoVs are susceptible to environmental factors due to the presence of viral lipid envelopes (UV rays, heat, desiccation, extreme $\mathrm{pH}$, temperature, and presence of detergents) (Plowright et al., 2015). While SARS-2 can live on the surface of materials for several hours (e.g., aluminium, sterile sponges, or latex surgical gloves), it is important to note that prolonged 
interaction with hostile natural environments causes rapid viral decay and harm to infectivity (Plowright et al., 2015; Sinclair et al., 2008). As a result, when predicting the probability of interspecies transmission, the precise location of viral flaking events as well as related environmental conditions should be taken into account (Wong et al., 2019).

\section{SARS-CoV-2 presence and survival in water and wastewater}

SARS-CoV-2 was lately found in water and wastewater. According to the most recent literature, the main way of coronavirus virus spread into water and wastewater is thought to be through the stools and masks of COVID-19 patients (Tran et al., 2021). For the first time in Quito, Ecuador (a low-sanitation) SARS-CoV-2 were detected in river water (Guerrero-Latorre et al., 2020). SARS-CoV-2 traces (nucleic acid remains) were lately discovered in wastewater treatment plant sludge (Kocamemi et al., 2020), community sewage, waste water, medical wastewater (Tran et al., 2021). The most popular way for COVID-19 to enter sewage and wastewater is through disease carrier excreta (Tran et al., 2021). The Netherlands performed the first research on the occurrence of SARS-CoV-2 in sewage (Medema et al., 2020) . Currently, it is known that SARS$\mathrm{CoV}-2$, once expelled from the host, will live in the atmosphere for only a few days in the absence of living cells (Liu et al., 2020b). Sewage water specimens were taken from six Dutch cities and Schiphol Airport's wastewater treatment plants (WWTPs) (Amsterdam, Den Haag, Utrecht, Apeldoorn, Amersfoort, Schiphol, and Tilburg). The COVID-19 disease virus was first discovered in waste water at Amsterdam Schiphol Airport's Tilburg WWTP and the Kaatsheuvel wastewater treatment facility, and according to findings. Since the sewage water was processed in the municipality wherever first person of COVID-19 resided in the Netherlands, sewage specimens were taken and tracked from municipal sewage treatment plants. The SARS-CoV-2 pandemic in water samples obtained from two different locations, according to the results. According to the authors, the very first water tester comprising the virus was tracked after 4 days where the first individual confirmed positive for SARS-CoV-2 coronavirus at Amsterdam Schiphol Airport. Given the global pandemic, this was a significant and interesting discovery (Medema et al., 2020). The RT-PCR is the most commonly used method for detecting SARSCoV-2 in a variety of testers (River water, sewage, and wastewater are both examples of contaminants) (RT-qPCR) (Ahmed et al., 2020b).

There is currently no public-domain research on the perseverance and sustainability of SARSCoV-2 in water or wastewater (Race et al., 2020). The existence periods of the SARS-CoV-1 and MERS-CoV coronaviruses formerly studied in the literature, on the other hand, can be used for orientation and comparative purposes. E.g, Wang et al. (2005a) SARS-CoV-1 opposition was investigated in several water matrices at $4{ }^{\circ} \mathrm{C}$ and $20^{\circ} \mathrm{C}$ (Wang et al., 2005). Another research revealed that SARS-CoV-1 can only live for couple of days in de-chlorinated drinkable water, hospitals wastewater, and municipal waste at 20 degrees Celsius. This clearly indicates that SARS-CoV-1 was successfully extracted in room temperature water. Other investigators came to the same conclusion, reporting that coronaviruses (human coronavirus 229E and animal feline infectious peritonitis coronavirus) expired off very quickly in wastewater samples, with a 99.9\% decrease in two to four days at $23{ }^{\circ} \mathrm{C}$ (Casanova et al., 2009). 


\section{Socio-economic and spiritual impact of SARS-CoV-2}

Panic and disease can stifle development, intake, leisure, travel, and overall well-being, while health is important to a prosperous productive society (Fourie, 2020). COVID-19 has global health consequences as well as wide-ranging structural disturbances. Rendering to Bloomberg, China's first-quarter GDP growth will fall to 4.5 percent, and global GDP (GDP) is projected to fall by 0.42 percent in the first quarter of 2020 (Bloomberg, 2020). Economists predict that if worldwide action is not taken quickly to eradicate the virus, China could lose up to 62 billion dollars in the first quarter of 2020, while the rest of the world would lose more than 280 billion dollars (Evans, 2020). Various governmental regulatory bodies in China have issued a series of financial policies to help ease the financial hardship caused by the novel coronavirus pandemic that has been ravaging the country since January 2020. Financial policies include offering preferential loan terms to some frontline businesses through financial institutions, lowering the costs of lending guarantee programs, and deferring loan repayment.

The UN World Tourism Organization has warned of a drop in international influxes and receipts in 2020 , lowering its forecast for foreign tourist comings to a $1 \%$ to $3 \%$ growth rate in 2020 , implying a $\$ 30-50$ billion loss in tourism industry receipts (UNWTO, 2020).

However, if the majority of COVID-19 infections were caused by people aged 15 to 44, those in the labor market, and parents of young children, the consequences for economic growth, malnutrition, and food production might be much worse (Evans, 2020). Indeed, during the outbreak, household income and consumption may fall dramatically, which may have a negative impact on the prevalence of under nutrition. The Chinese welfare state has interlaced a robust community safety net to alleviate Chinese society's social suffering during the mid- and postcrisis times (Lu et al., 2020b). Various forms of social policy systems, such as social security, social aid, and social welfare arrangements, have been integrated and synthesized (Lu et al., 2020b). Faced with the complexities of new threats posed by the pandemic, the Chinese government's cooperation with intermediary social welfare organizations has been critical in delivering both cash aids and social amenities (benefits in kind) (Lu et al., 2020a).

Children and women have been subjected to many forms of child abuse (including sexual harassment and violence towards girls) as a result of quarantine and school closures, resulting in weeks of missed schooling, with long-term consequences such as mental distress and unintended pregnancies (Evans, 2020).

In fact, the COVID-19's economic consequences damage not just to public health infrastructure but also transport and logistics, food and agriculture sectors, different corporate kinds, and trade chains, to name a few (Evans, 2020). These businesses are not often associated with disease impact evaluations, but they face the risk of the outbreak, in which customers are reluctant to use their facilities due to a faulty supply chain or a depleted workforce (Evans, 2020). Religiousness can be one of the most powerful ways to promote mental relaxation during a COVID-19 outbreak. Spirituality can aid in mental easing during times of disaster and hazardous diseases. Since the number and rate of deaths are updated and recorded on a daily basis during the pandemic, faith can be a valuable sedative in societies dealing with the epidemic (Vaillant, 
2013). Spirituality and faith may be of assistance to people in times of bereavement and crisis (Krysinska et al., 2014). Religions strengthen human mental health by introducing health initiatives, offering social provision, and improving self-efficacy and solidarity (George et al., 2002). For example, nearly 1,400 years ago, the Prophet of Islam said, "If you hear that plague or some other risky communicable disease has wrecked out in a country, do not go there; but if it breaks out in a land where you are staying, stay at home in your house" (Ghareeb, 2010). "Cleanliness is half of the faith and faith leads a man to heaven", said the Prophet of Islam in another part (Maigari, 2016). In addition, ablution (wudhu) is among the five daily Islamic cleaning practices in which an individual rinses his hands, forearms, mouth, nose, ears, face, hairs, ankles, and feet 3 times each (Maigari, 2016). Ironically, it contains all of the most powerful methods of coping with COVID-19, and it forces one to rethink certain Human and social principles.

\section{Conclusions}

The SARS-CoV-2 outbreak (also known as 2019-nCoV or COVID-19) is like to the SARS CoV-1 and MERS-CoV outbreaks that occurred as smaller outbreaks in China and Saudi Arabia, respectively. To date, the SARS-CoV-2 death rate is (approximately 9\% if not overestimated) is lesser than that of SARS-CoV-1 (9.6\%) and much lower than that of MERSCoV (approximately 35\%), which emerged in 2019, 2003, and 2017, respectively. While the mortality rate between SARS-1 and SARS-2 is negligible, and considering the widely occurring viral mutations, one question remains about the inadequate measures (scientific, political, sanitary, logistic...) implemented worldwide since 2003 to prevent such new SARS-CoVs pandemics from becoming a recurring global epidemic. Rapid, responsive, and highly precise pathogen tests, as well as potential differential diagnosis based on clinical representation, are unquestionably needed to aid in the control and prevention of the rapidly emerging COVID-19, which is essential for clinicians in their first interaction with the supposed patient. In addition, close monitoring is necessary to track its upcoming host alteration, viral growth, infectivity, transmissibility, and pathogenicity. In terms of genetic evolution, receptor binding, and pathogenesis, SARS-CoV-2 is identical to SARS-CoV-1. SARS-CoV-2 must have evolved from a alteration in the previously existing SARS-CoV-1 (although the hypothesis of a human manipulation is still not discarded). The FDA has currently approved an EUA for the PfizerBioNTech COVID-19 (BNT162b2) vaccine (Pfizer, Inc; Philadelphia, Pennsylvania) and the Oxford-AstraZeneca COVID-19 vaccine (AZD1222) developed by Oxford University and AstraZeneca. These two vaccines have been introduced into the human population for the purposes of control and prevention. Hydroxychloroquine, either alone or in conjunction with the macrolide antibiotic azithromycin, has shown cost-effective therapeutic options and a substantial reduction in treatment time during the initial infection cycle. Nonetheless, it has sparked debate, especially in France, and it is unclear if it will be accepted globally one day. The vaccine is thought to be the best alternative for SARS-CoV-2 infection prevention and control, but the problem of variants is becoming more prevalent. Important targets for neutralizing antibodies during viral entry are $\mathrm{S}$ glycoprotein and $\mathrm{RBD}$, which was the primary goal for coronavirus immunogen design and vaccine growth. For a long time, many viruses were found in their natural reservoirs. Human activities such as current agricultural practices and urbanization, which change habitats, are primarily responsible for the persistent transmission of viruses from 
common hosts to humans and other animals. Animals are the source of approximately 60 percent of recently developing and re-emerging pathogens. Since animals roost in our backyards and farms instead of forests (e.g., Amazonia/Amazon rain forest), an alert system must carefully consider the continuing cutting down of forests (e.g., Amazonia/Amazon rain forest). As a result, the clearest method to avoid viral zoonosis is to keep the barrier among natural reservoirs and human culture in attention of the one health principle.

Author Contributions: The published form of the manuscript has been read and permitted by all authors. All authors have contributed to the writing, formal data analysis, data curation, methodology and data validation. F.M. supervised the work, revised, edited, and submitted the final type of this manuscript.

Funding: This research received no external funding.

Acknowledgments: The authors thank Dr. Abder Menaa, MD, as well as all our colleagues worldwide and COVID patients, for insightful discussions on this topic.

Conflicts of Interest: The authors declare no conflict of interest.

\section{List of Abbreviations}

$\alpha-\mathrm{CoV}$ :

ACE2:

ACIP:

AKI:

$\beta-\mathrm{CoV}$ :

Bat-SL-CoVZC45:

Bat-SL-CoVZXC21:

CDC:

CK:

CNS:

COVID-19:

$\operatorname{CoV}(\mathrm{s})$ :

CP:

CT:

$\delta$-CoV:

DNA:

DPP4:

ECMO:
Alpha Coronavirus

Angiotensin-Converting Enzyme

Advisory Committee on Immunization Practices

Acute Kidney Injury

Beta Coronavirus

Bat-Derived SARS-Like Coronaviruses

Centre for Diseases Control and Prevention

Creatine Kinase

Central Nervous System

Coronavirus Diseases-19

Coronaviruse(s)

Convalescent Plasma

Computer Tomography

Delta Coronavirus

Deoxyribonucleic Acid

Dipeptidyl Peptidase 4

Extracorporeal Membrane Oxygenation 


$\begin{array}{ll}\text { EISs } & \text { Electrochemical Sensors } \\ \text { ER: } & \text { Endoplasmic Reticulum } \\ \text { ERGIC: } & \text { Endoplasmic Reticulum-Golgi Intermediate Compartment } \\ \text { FDA: } & \text { Food and Drug Administration } \\ \gamma \text {-CoV: } & \text { Gamma Coronavirus } \\ \text { GDP: } & \text { Gross Domestic Product } \\ \text { HCoV: } & \text { Human Coronavirus } \\ \text { HCoV-229E: } & \text { Human Coronavirus 229E } \\ \text { HCoV-NL63: } & \text { Human Coronavirus NL63 } \\ \text { HCoV-OC43: } & \text { Human Coronavirus OC43 } \\ \text { ICU: } & \text { Intensive Care Unit } \\ \text { IL10: } & \text { Interleukin 10 } \\ \text { IL4: } & \text { Interleukin } 4 \\ \text { LFA: } & \text { Lateral flow assay } \\ \text { LDH: } & \text { Lactate Dehydrogenase } \\ \text { LMWH: } & \text { Low Molecular Weight Heparin } \\ \text { MERS-CoV: } & \text { Middle East Respiratory Syndrome Coronavirus } \\ \text { MHV: } & \text { Mouse Hepatitis Virus } \\ \text { MS: } & \text { Multiple Sclerosis } \\ \text { MuCoV: } & \text { Murine Coronavirus } \\ \text { MUSCLE: } & \text { Multiple Sequence Comparison by Log-Expectation } \\ \text { ORF: } & \text { Open Reading Frame } \\ \text { PCR: } & \text { Polymerase Chain Reaction } \\ \text { PEDV: } & \text { Porcine Epidemic Diarrhea Virus } \\ \text { PNAs: } & \text { Peptide Nucleic Acid } \\ \text { RA: } & \text { Rheumatoid Arthritis } \\ \text { RBD: } & \text { Receptor Binding Domain } \\ \text { RdDp: } & \text { RNA Dependent RNA Polymerase } \\ \text { RDS: } & \end{array}$




\begin{tabular}{|c|c|}
\hline RNA: & Ribonucleic Acid \\
\hline RSCU: & Relative Synonymous Codon Usage \\
\hline RTC: & Replication/Transcription Complex \\
\hline RT-PCR: & Reverse Transcription Polymerase Chain Reaction \\
\hline S1-CTD: & S1-Carboxy Terminal Domain \\
\hline S1-NTD: & S1-Amino Terminal Domain \\
\hline SADS: & Swine Acute Diarrhoea Syndrome \\
\hline SARS-2: & Severe Acute Respiratory Syndrome-2 \\
\hline SARS-CoV-1: & Severe Acute Respiratory Syndrome Coronavirus- 1 \\
\hline SARS-CoV-2: & Severe Acute Respiratory Syndrome Coronavirus- 2 \\
\hline SARSr-CoVs: & SARS Related Coronaviruses \\
\hline SEM: & Scanning Electron Microscopy \\
\hline SLE: & Systemic Lupus Erythematous \\
\hline ssRNA: & Single Standard Ribonucleic Acid \\
\hline TCM: & Traditional Chinese Medicine \\
\hline TEM: & Transmission Electron Microscopy \\
\hline TGEV: & Transmissible Gastroenteritis Virus \\
\hline Th2: & T-helper-2 \\
\hline UK: & United Kingdom \\
\hline UNWTO: & United Nation World Tourism Organization \\
\hline USA: & United State of America \\
\hline WHO: & World Health Organization \\
\hline WWTPs: & Wastewater Treatment Plants \\
\hline
\end{tabular}




\section{References}

Adeleye, O.A., Bamiro, O.A., Bakre, L.G., Odeleye, F.O., Adebowale, M.N., Okunye, O.L., Sodeinde, M.A., Adebona, A.C., Menaa, F., 2021. Medicinal Plants with Potential Inhibitory Bioactive Compounds against Coronaviruses. Adv Pharm Bull.

Agrawal, A.S., Tao, X., Algaissi, A., Garron, T., Narayanan, K., Peng, B.-H., Couch, R.B., Tseng, C.T.K., 2016. Immunization with inactivated Middle East Respiratory Syndrome coronavirus vaccine leads to lung immunopathology on challenge with live virus. Hum Vaccin Immunother 12, 2351-2356.

Ahmed, S.F., Quadeer, A.A., McKay, M.R., 2020a. Preliminary Identification of Potential Vaccine Targets for the COVID-19 Coronavirus (SARS-CoV-2) Based on SARS-CoV Immunological Studies. Viruses 12.

Ahmed, W., Angel, N., Edson, J., Bibby, K., Bivins, A., O'Brien, J.W., Choi, P.M., Kitajima, M., Simpson, S.L., Li, J., Tscharke, B., Verhagen, R., Smith, W.J.M., Zaugg, J., Dierens, L., Hugenholtz, P., Thomas, K.V., Mueller, J.F., 2020b. First confirmed detection of SARS-CoV-2 in untreated wastewater in Australia: A proof of concept for the wastewater surveillance of COVID-19 in the community. The Science of the total environment 728, 138764.

Ahsan, W., Javed, S., Bratty, M.A., Alhazmi, H.A., Najmi, A., 2020. Treatment of SARS-CoV-2: How far have we reached? Drug discoveries \& therapeutics 14, 67-72.

Ai, T., Yang, Z., Hou, H., Zhan, C., Chen, C., Lv, W., Tao, Q., Sun, Z., Xia, L., 2020. Correlation of Chest CT and RT-PCR Testing in Coronavirus Disease 2019 (COVID-19) in China: A Report of 1014 Cases. Radiology, 200642.

Alagaili, A.N., Briese, T., Mishra, N., Kapoor, V., Sameroff, S.C., Burbelo, P.D., de Wit, E., Munster, V.J., Hensley, L.E., Zalmout, I.S., Kapoor, A., Epstein, J.H., Karesh, W.B., Daszak, P., Mohammed, O.B., Lipkin, W.I., 2014. Middle East respiratory syndrome coronavirus infection in dromedary camels in Saudi Arabia. mBio 5, e00884.

Andersen, K.G., Rambaut, A., Lipkin, W.I., Holmes, E.C., Garry, R.F., 2020. The proximal origin of SARS-CoV-2. Nature medicine 26, 450-452.

Arabi, Y.M., Alothman, A., Balkhy, H.H., Al-Dawood, A., AlJohani, S., Al Harbi, S., Kojan, S., Al Jeraisy, M., Deeb, A.M., Assiri, A.M., Al-Hameed, F., AlSaedi, A., Mandourah, Y., Almekhlafi, G.A., Sherbeeni, N.M., Elzein, F.E., Memon, J., Taha, Y., Almotairi, A., Maghrabi, K.A., Qushmaq, I., Al Bshabshe, A., Kharaba, A., Shalhoub, S., Jose, J., Fowler, R.A., Hayden, F.G., Hussein, M.A., And the, M.t.g., 2018. Treatment of Middle East Respiratory Syndrome with a combination of lopinavir-ritonavir and interferon- $\beta 1 \mathrm{~b}$ (MIRACLE trial): study protocol for a randomized controlled trial. Trials 19, 81-81.

Ashour, H.M., Elkhatib, W.F., Rahman, M.M., Elshabrawy, H.A., 2020. Insights into the Recent 2019 Novel Coronavirus (SARS-CoV-2) in Light of Past Human Coronavirus Outbreaks. Pathogens (Basel, Switzerland) 9.

Assiri, A., Al-Tawfiq, J.A., Al-Rabeeah, A.A., Al-Rabiah, F.A., Al-Hajjar, S., Al-Barrak, A., Flemban, H., Al-Nassir, W.N., Balkhy, H.H., Al-Hakeem, R.F., Makhdoom, H.Q., Zumla, A.I., Memish, Z.A., 
2013. Epidemiological, demographic, and clinical characteristics of 47 cases of Middle East respiratory syndrome coronavirus disease from Saudi Arabia: a descriptive study. Lancet Infect Dis 13, 752-761.

Barazzoni, R., Bischoff, S.C., Breda, J., Wickramasinghe, K., Krznaric, Z., Nitzan, D., Pirlich, M., Singer, P., 2020. ESPEN expert statements and practical guidance for nutritional management of individuals with SARS-CoV-2 infection. Clinical nutrition (Edinburgh, Scotland) 39, 1631-1638.

Baron, S.A., Devaux, C., Colson, P., Raoult, D., Rolain, J.-M., 2020. Teicoplanin: an alternative drug for the treatment of coronavirus COVID-19. International journal of antimicrobial agents 105944.

Beusekom, M.V., 2021. Pfizer, AstraZeneca COVID-19 vaccines may offer high efficacy in elderly. https://www.cidrap.umn.edu/news-perspective/2021/03/pfizer-astrazeneca-covid-19-vaccines-may-offerhigh-efficacy-elderly.

Biot, C., Daher, W., Chavain, N., Fandeur, T., Khalife, J., Dive, D., De Clercq, E., 2006. Design and synthesis of hydroxyferroquine derivatives with antimalarial and antiviral activities. Journal of medicinal chemistry 49, 2845-2849.

Bleyzac, N., Goutelle, S., Bourguignon, L., Tod, M., 2020. Azithromycin for COVID-19: More Than Just an Antimicrobial? Clin Drug Investig 40, 683-686.

Bloomberg, 2020. Charting the Global Economic Impact of the Coronavirus.

https://www.bloomberg.com/graphics/2020 - global - economic - impact - of - wuhan - novel coronavirus/.

Boopathi, S., Poma, A.B., Kolandaivel, P., 2020. Novel 2019 coronavirus structure, mechanism of action, antiviral drug promises and rule out against its treatment. Journal of Biomolecular Structure and Dynamics, 1-10.

Brahim Belhaouari, D., Fontanini, A., Baudoin, J.-P., Haddad, G., Le Bideau, M., Bou Khalil, J.Y., Raoult, D., La Scola, B., 2020. The Strengths of Scanning Electron Microscopy in Deciphering SARSCoV-2 Infectious Cycle. Frontiers in microbiology 11.

Callaway, E., 2020. The coronavirus is mutating - does it matter? Nature 585, 174-177.

Caly, L., Druce, J.D., Catton, M.G., Jans, D.A., Wagstaff, K.M., 2020. The FDA-approved Drug Ivermectin inhibits the replication of SARS-CoV-2 in vitro. Antiviral research, 104787.

Casadevall, A., Pirofski, L.A., 2020. The convalescent sera option for containing COVID-19. The Journal of clinical investigation 130, 1545-1548.

Casanova, L., Rutala, W.A., Weber, D.J., Sobsey, M.D., 2009. Survival of surrogate coronaviruses in water. Water research 43, 1893-1898.

Cascella, M., Rajnik, M., Cuomo, A., Dulebohn, S.C., Di Napoli, R., 2020. Features, evaluation and treatment coronavirus (COVID-19), Statpearls [internet]. StatPearls Publishing. 
Chai, X., Hu, L., Zhang, Y., Han, W., Lu, Z., Ke, A., Zhou, J., Shi, G., Fang, N., Fan, J., Cai, J., Fan, J., Lan, F., 2020. Specific ACE2 Expression in Cholangiocytes May Cause Liver Damage After 2019-nCoV Infection. bioRxiv, 2020.2002.2003.931766.

Chan, J.F., Yuan, S., Kok, K.H., To, K.K., Chu, H., Yang, J., Xing, F., Liu, J., Yip, C.C., Poon, R.W., Tsoi, H.W., Lo, S.K., Chan, K.H., Poon, V.K., Chan, W.M., Ip, J.D., Cai, J.P., Cheng, V.C., Chen, H., Hui, C.K., Yuen, K.Y., 2020. A familial cluster of pneumonia associated with the 2019 novel coronavirus indicating person-to-person transmission: a study of a family cluster. Lancet 395, 514-523.

Chartrand, C., Tremblay, N., Renaud, C., Papenburg, J., 2015. Diagnostic Accuracy of Rapid Antigen Detection Tests for Respiratory Syncytial Virus Infection: Systematic Review and Meta-analysis. Journal of clinical microbiology 53, 3738-3749.

Chau, C.H., Strope, J.D., Figg, W.D., 2020. COVID-19 Clinical Diagnostics and Testing Technology. Pharmacotherapy 40, 857-868.

Chen, L., Xiong, J., Bao, L., Shi, Y., 2020a. Convalescent plasma as a potential therapy for COVID-19. Lancet Infect Dis 20, 398-400.

Chen, N., Zhou, M., Dong, X., Qu, J., Gong, F., Han, Y., Qiu, Y., Wang, J., Liu, Y., Wei, Y., Xia, J., Yu, T., Zhang, X., Zhang, L., 2020b. Epidemiological and clinical characteristics of 99 cases of 2019 novel coronavirus pneumonia in Wuhan, China: a descriptive study. Lancet 395, 507-513.

Chen, Y., Lu, S., Jia, H., Deng, Y., Zhou, J., Huang, B., Yu, Y., Lan, J., Wang, W., Lou, Y., Qin, K., Tan, W., 2017. A novel neutralizing monoclonal antibody targeting the N-terminal domain of the MERS-CoV spike protein. Emerg Microbes Infect 6, e37-e37.

Cheng, Y., Wong, R., Soo, Y.O., Wong, W.S., Lee, C.K., Ng, M.H., Chan, P., Wong, K.C., Leung, C.B., Cheng, G., 2005. Use of convalescent plasma therapy in SARS patients in Hong Kong. European journal of clinical microbiology \& infectious diseases : official publication of the European Society of Clinical Microbiology 24, 44-46.

Chi, H., Zheng, X., Wang, X., Wang, C., Wang, H., Gai, W., Perlman, S., Yang, S., Zhao, J., Xia, X., 2017. DNA vaccine encoding Middle East respiratory syndrome coronavirus S1 protein induces protective immune responses in mice. Vaccine 35, 2069-2075.

China, 2020a. Technical Guide for Prevention and Control of New Coronavirus Infection in Medical Institutions (Second Edition). . http://www.nhc.gov.cn/jkj/s3577/202001/c67cfe29ecf1470e8c7fc47d3b751e88.shtml.

China, 2020b. Transcript of press conference in 17, February, 2020 . http://www.nhc.gov.cn/xcs/s3574/.

Chinese, S.M.E.C., 2004. Molecular evolution of the SARS coronavirus during the course of the SARS epidemic in China. Science 303, 1666-1669.

Chowell, G., Abdirizak, F., Lee, S., Lee, J., Jung, E., Nishiura, H., Viboud, C., 2015. Transmission characteristics of MERS and SARS in the healthcare setting: a comparative study. BMC Med 13, 210210. 
Christian, M.D., Poutanen, S.M., Loutfy, M.R., Muller, M.P., Low, D.E., 2004. Severe acute respiratory syndrome. Clin Infect Dis 38, 1420-1427.

Chu, C.M., Cheng, V.C.C., Hung, I.F.N., Wong, M.M.L., Chan, K.H., Chan, K.S., Kao, R.Y.T., Poon, L.L.M., Wong, C.L.P., Guan, Y., Peiris, J.S.M., Yuen, K.Y., Group, H.U.S.S., 2004. Role of lopinavir/ritonavir in the treatment of SARS: initial virological and clinical findings. Thorax 59, 252-256.

Coleman, C.M., Venkataraman, T., Liu, Y.V., Glenn, G.M., Smith, G.E., Flyer, D.C., Frieman, M.B., 2017. MERS-CoV spike nanoparticles protect mice from MERS-CoV infection. Vaccine 35, 1586-1589.

Colson, P., Rolain, J.-M., Raoult, D., 2020. Chloroquine for the 2019 novel coronavirus SARS-CoV-2. International journal of antimicrobial agents 55, 105923.

Couzin-Frankel, J., 2020. The mystery of the pandemic's 'happy hypoxia'. Science 368, 455.

Cox, M.J., Loman, N., Bogaert, D., O'Grady, J., 2020. Co-infections: potentially lethal and unexplored in COVID-19. The Lancet. Microbe 1, e11.

Cragg, G.M., Newman, D.J., 2013. Natural products: a continuing source of novel drug leads. Biochimica et biophysica acta 1830, 3670-3695.

Cui, J., Li, F., Shi, Z.-L., 2019. Origin and evolution of pathogenic coronaviruses. Nat Rev Microbiol 17, 181-192.

Cunningham, C.H., Stuart, H.O., 1947. Cultivation of the virus of infectious bronchitis of chickens in embryonated chicken eggs. American journal of veterinary research 8, 209-212.

De Groot, R.J.B., S.C.; Baric, R.; Enjuanes, L.; Gorbalenya, A.E.; Holmes, K.V.; Perlman, S.; Poon, L.;Rottier, P.J.M.; Talbot, P.J.; et al., 2011. Family Coronaviridae. In Virus Taxonomy, Classification and Nomenclature of Viruses. Ninth Report of the International Committee on Taxonomy of Viruses. 1st, 806-826.

Decaro, N., 2011a. Alphacoronavirus Springer New York, New York, NY, pp. 371-383.

Decaro, N., 2011b. Betacoronavirust, in: Tidona, C., Darai, G. (Eds.), The Springer Index of Viruses. Springer New York, New York, NY, pp. 385-401.

Decaro, N., 2011c. Gammacoronavirust, in: Tidona, C., Darai, G. (Eds.), The Springer Index of Viruses. Springer New York, New York, NY, pp. 403-413.

Deng, C.X., 2020. The global battle against SARS-CoV-2 and COVID-19. International journal of biological sciences 16, 1676-1677.

Deng, S.Q., Peng, H.J., 2020. Characteristics of and Public Health Responses to the Coronavirus Disease 2019 Outbreak in China. Journal of clinical medicine 9. 
Deng, Y., Lan, J., Bao, L., Huang, B., Ye, F., Chen, Y., Yao, Y., Wang, W., Qin, C., Tan, W., 2018. Enhanced protection in mice induced by immunization with inactivated whole viruses compare to spike protein of middle east respiratory syndrome coronavirus. Emerg Microbes Infect 7, 60-60.

Devaux, C.A., Rolain, J.M., Colson, P., Raoult, D., 2020. New insights on the antiviral effects of chloroquine against coronavirus: what to expect for COVID-19? International journal of antimicrobial agents, 105938.

Du, L., Kou, Z., Ma, C., Tao, X., Wang, L., Zhao, G., Chen, Y., Yu, F., Tseng, C.-T.K., Zhou, Y., Jiang, S., 2013a. A truncated receptor-binding domain of MERS-CoV spike protein potently inhibits MERS$\mathrm{CoV}$ infection and induces strong neutralizing antibody responses: implication for developing therapeutics and vaccines. PLoS One 8, e81587-e81587.

Du, L., Zhao, G., Kou, Z., Ma, C., Sun, S., Poon, V.K.M., Lu, L., Wang, L., Debnath, A.K., Zheng, B.-J., Zhou, Y., Jiang, S., 2013b. Identification of a receptor-binding domain in the $S$ protein of the novel human coronavirus Middle East respiratory syndrome coronavirus as an essential target for vaccine development. J Virol 87, 9939-9942.

Duan, K., Liu, B., Li, C., Zhang, H., Yu, T., Qu, J., Zhou, M., Chen, L., Meng, S., Hu, Y., Peng, C., Yuan, M., Huang, J., Wang, Z., Yu, J., Gao, X., Wang, D., Yu, X., Li, L., Zhang, J., Wu, X., Li, B., Xu, Y., Chen, W., Peng, Y., Hu, Y., Lin, L., Liu, X., Huang, S., Zhou, Z., Zhang, L., Wang, Y., Zhang, Z., Deng, K., Xia, Z., Gong, Q., Zhang, W., Zheng, X., Liu, Y., Yang, H., Zhou, D., Yu, D., Hou, J., Shi, Z., Chen, S., Chen, Z., Zhang, X., Yang, X., 2020. Effectiveness of convalescent plasma therapy in severe COVID-19 patients. Proc Natl Acad Sci U S A 117, 9490-9496.

Elengoe, A., 2020. COVID-19 Outbreak in Malaysia. Osong public health and research perspectives 11, 93-100.

Estcourt, L.J., Roberts, D.J., 2020. Convalescent plasma for covid-19. BMJ 370, m3516.

Evans, O., 2020. Socio-economic impacts of novel coronavirus: The policy solutions. BizEcons Quarterly 7, 3-12.

Fan, Y., Zhao, K., Shi, Z.-L., Zhou, P., 2019. Bat Coronaviruses in China. Viruses 11, 210.

FDA, 2020. FDA updates on hand sanitizers consumers should not use. https://www.fda.gov/drugs/drugsafety-and-availability/fda-updates-hand-sanitizers-consumers-should-not-use.

Findlater, A., Bogoch, I.I., 2018. Human Mobility and the Global Spread of Infectious Diseases: A Focus on Air Travel. Trends Parasitol 34, 772-783.

Forni, D., Cagliani, R., Clerici, M., Sironi, M., 2017a. Molecular Evolution of Human Coronavirus Genomes. Trends Microbiol 25, 35-48.

Forni, D., Cagliani, R., Clerici, M., Sironi, M., 2017b. Molecular Evolution of Human Coronavirus Genomes. Trends Microbiol 25, 35-48. 
Fourie, J., 2020. Beyond 2020: a vision of a prosperous South Africa-economy: opinion. finweek 2020, 44.

Gao, J., Tian, Z., Yang, X., 2020. Breakthrough: Chloroquine phosphate has shown apparent efficacy in treatment of COVID-19 associated pneumonia in clinical studies. Bioscience trends 14, 72-73.

Gautret, P., Lagier, J.C., Parola, P., Hoang, V.T., Meddeb, L., Mailhe, M., Doudier, B., Courjon, J., Giordanengo, V., Vieira, V.E., Tissot Dupont, H., Honoré, S., Colson, P., Chabrière, E., La Scola, B., Rolain, J.M., Brouqui, P., Raoult, D., 2020. Hydroxychloroquine and azithromycin as a treatment of COVID-19: results of an open-label non-randomized clinical trial. International journal of antimicrobial agents $56,105949$.

George, L.K., Ellison, C.G., Larson, D.B., 2002. Explaining the Relationships between Religious Involvement and Health. Psychological Inquiry 13, 190-200.

Ghareeb, B.A.A., 2010. Genetics of Diseases, Ethics and Beauty in Selection of Mates (An Islamic Perspective). Med J Islamic World Acad Sci 18, 155-164.

Gorbalenya, A.E., Baker, S.C., Baric, R.S., de Groot, R.J., Drosten, C., Gulyaeva, A.A., Haagmans, B.L., Lauber, C., Leontovich, A.M., Neuman, B.W., Penzar, D., Perlman, S., Poon, L.L.M., Samborskiy, D., Sidorov, I.A., Sola, I., Ziebuhr, J., 2020. $<$ em $>$ Severe acute respiratory syndrome-related coronavirus $</$ em $>$ : The species and its viruses - a statement of the Coronavirus Study Group. bioRxiv, 2020.2002.2007.937862.

Graham, R.L., Baric, R.S., 2010. Recombination, reservoirs, and the modular spike: mechanisms of coronavirus cross-species transmission. J Virol 84, 3134-3146.

Grein, J., Ohmagari, N., Shin, D., Diaz, G., Asperges, E., Castagna, A., Feldt, T., Green, G., Green, M.L., Lescure, F.X., Nicastri, E., Oda, R., Yo, K., Quiros-Roldan, E., Studemeister, A., Redinski, J., Ahmed, S., Bernett, J., Chelliah, D., Chen, D., Chihara, S., Cohen, S.H., Cunningham, J., D'Arminio Monforte, A., Ismail, S., Kato, H., Lapadula, G., L'Her, E., Maeno, T., Majumder, S., Massari, M., Mora-Rillo, M., Mutoh, Y., Nguyen, D., Verweij, E., Zoufaly, A., Osinusi, A.O., DeZure, A., Zhao, Y., Zhong, L., Chokkalingam, A., Elboudwarej, E., Telep, L., Timbs, L., Henne, I., Sellers, S., Cao, H., Tan, S.K., Winterbourne, L., Desai, P., Mera, R., Gaggar, A., Myers, R.P., Brainard, D.M., Childs, R., Flanigan, T., 2020. Compassionate Use of Remdesivir for Patients with Severe Covid-19. N Engl J Med 382, 23272336.

Grubaugh, N.D., Hanage, W.P., Rasmussen, A.L., 2020. Making sense of mutation: what D614G means for the COVID-19 pandemic remains unclear. Cell 182, 794-795.

Guerrero-Latorre, L., Ballesteros, I., Villacrés-Granda, I., Granda, M.G., Freire-Paspuel, B., Ríos-Touma, B., 2020. SARS-CoV-2 in river water: Implications in low sanitation countries. The Science of the total environment $743,140832$.

Gui, M., Song, W., Zhou, H., Xu, J., Chen, S., Xiang, Y., Wang, X., 2017. Cryo-electron microscopy structures of the SARS-CoV spike glycoprotein reveal a prerequisite conformational state for receptor binding. Cell Res 27, 119-129. 
Harrison, C., 2020. Coronavirus puts drug repurposing on the fast track. Nature biotechnology 38, 379381.

He, J., Tao, H., Yan, Y., Huang, S.-Y., Xiao, Y., 2020. Molecular Mechanism of Evolution and Human Infection with SARS-CoV-2. Viruses 12, 428.

Hindson, J., 2020. COVID-19: faecal-oral transmission? Nature Reviews Gastroenterology \& Hepatology 17, 259-259.

Holmes, E.C., Rambaut, A., 2004. Viral evolution and the emergence of SARS coronavirus. Philos Trans R Soc Lond B Biol Sci 359, 1059-1065.

Holshue, M.L., DeBolt, C., Lindquist, S., Lofy, K.H., Wiesman, J., Bruce, H., Spitters, C., Ericson, K., Wilkerson, S., Tural, A., Diaz, G., Cohn, A., Fox, L., Patel, A., Gerber, S.I., Kim, L., Tong, S., Lu, X., Lindstrom, S., Pallansch, M.A., Weldon, W.C., Biggs, H.M., Uyeki, T.M., Pillai, S.K., 2020. First Case of 2019 Novel Coronavirus in the United States. N Engl J Med 382, 929-936.

Hon, C.-C., Lam, T.-Y., Shi, Z.-L., Drummond, A.J., Yip, C.-W., Zeng, F., Lam, P.-Y., Leung, F.C.-C., 2008. Evidence of the recombinant origin of a bat severe acute respiratory syndrome (SARS)-like coronavirus and its implications on the direct ancestor of SARS coronavirus. J Virol 82, 1819-1826.

Hu, B., Ge, X., Wang, L.-F., Shi, Z., 2015. Bat origin of human coronaviruses. Virology Journal 12, 221.

Hu, B., Zeng, L.-P., Yang, X.-L., Ge, X.-Y., Zhang, W., Li, B., Xie, J.-Z., Shen, X.-R., Zhang, Y.-Z., Wang, N., Luo, D.-S., Zheng, X.-S., Wang, M.-N., Daszak, P., Wang, L.-F., Cui, J., Shi, Z.-L., 2017. Discovery of a rich gene pool of bat SARS-related coronaviruses provides new insights into the origin of SARS coronavirus. PLoS Pathog 13, e1006698-e1006698.

Huang, C., Wang, Y., Li, X., Ren, L., Zhao, J., Hu, Y., Zhang, L., Fan, G., Xu, J., Gu, X., Cheng, Z., Yu, T., Xia, J., Wei, Y., Wu, W., Xie, X., Yin, W., Li, H., Liu, M., Xiao, Y., Gao, H., Guo, L., Xie, J., Wang, G., Jiang, R., Gao, Z., Jin, Q., Wang, J., Cao, B., 2020a. Clinical features of patients infected with 2019 novel coronavirus in Wuhan, China. Lancet, S0140-6736(0120)30183-30185.

Huang, P., Liu, T., Huang, L., Liu, H., Lei, M., Xu, W., Hu, X., Chen, J., Liu, B., 2020b. Use of Chest CT in Combination with Negative RT-PCR Assay for the 2019 Novel Coronavirus but High Clinical Suspicion. Radiology 295, 22-23.

Huang, Y., Yang, C., Xu, X.-f., Xu, W., Liu, S.-w., 2020c. Structural and functional properties of SARSCoV-2 spike protein: potential antivirus drug development for COVID-19. Acta Pharmacologica Sinica 41, 1141-1149.

Huang, Y.W., Dickerman, A.W., Piñeyro, P., Li, L., Fang, L., Kiehne, R., Opriessnig, T., Meng, X.J., 2013. Origin, evolution, and genotyping of emergent porcine epidemic diarrhea virus strains in the United States. mBio 4, e00737-00713.

Hui, D.S., I Azhar, E., Madani, T.A., Ntoumi, F., Kock, R., Dar, O., Ippolito, G., McHugh, T.D., Memish, Z.A., Drosten, C., Zumla, A., Petersen, E., 2020. The continuing 2019-nCoV epidemic threat of novel 
coronaviruses to global health - The latest 2019 novel coronavirus outbreak in Wuhan, China. Int J Infect Dis 91, 264-266.

Hui, D.S.C., Zumla, A., 2019. Severe Acute Respiratory Syndrome: Historical, Epidemiologic, and Clinical Features. Infect Dis Clin North Am 33, 869-889.

Hung, I.F., Lung, K.C., Tso, E.Y., Liu, R., Chung, T.W., Chu, M.Y., Ng, Y.Y., Lo, J., Chan, J., Tam, A.R., Shum, H.P., Chan, V., Wu, A.K., Sin, K.M., Leung, W.S., Law, W.L., Lung, D.C., Sin, S., Yeung, P., Yip, C.C., Zhang, R.R., Fung, A.Y., Yan, E.Y., Leung, K.H., Ip, J.D., Chu, A.W., Chan, W.M., Ng, A.C., Lee, R., Fung, K., Yeung, A., Wu, T.C., Chan, J.W., Yan, W.W., Chan, W.M., Chan, J.F., Lie, A.K., Tsang, O.T., Cheng, V.C., Que, T.L., Lau, C.S., Chan, K.H., To, K.K., Yuen, K.Y., 2020. Triple combination of interferon beta-1b, lopinavir-ritonavir, and ribavirin in the treatment of patients admitted to hospital with COVID-19: an open-label, randomised, phase 2 trial. Lancet 395, 1695-1704.

Ithete, N.L., Stoffberg, S., Corman, V.M., Cottontail, V.M., Richards, L.R., Schoeman, M.C., Drosten, C., Drexler, J.F., Preiser, W., 2013. Close relative of human Middle East respiratory syndrome coronavirus in bat, South Africa. Emerg Infect Dis 19, 1697-1699.

Jahanshahlu, L., Rezaei, N., 2020. Monoclonal antibody as a potential anti-COVID-19. Biomedicine \& pharmacotherapy $=$ Biomedecine \& pharmacotherapie 129, 110337.

Ji, T., Liu, Z., Wang, G., Guo, X., Akbar Khan, S., Lai, C., Chen, H., Huang, S., Xia, S., Chen, B., Jia, H., Chen, Y., Zhou, Q., 2020a. Detection of COVID-19: A review of the current literature and future perspectives. Biosensors \& bioelectronics 166, 112455.

Ji, W., Wang, W., Zhao, X., Zai, J., Li, X., 2020b. Homologous recombination within the spike glycoprotein of the newly identified coronavirus may boost cross-species transmission from snake to human. J Med Virol, 10.1002/jmv.25682.

Jiaming, L., Yanfeng, Y., Yao, D., Yawei, H., Linlin, B., Baoying, H., Jinghua, Y., Gao, G.F., Chuan, Q., Wenjie, T., 2017. The recombinant $\mathrm{N}$-terminal domain of spike proteins is a potential vaccine against Middle East respiratory syndrome coronavirus (MERS-CoV) infection. Vaccine 35, 10-18.

Jin, Y.-H., Cai, L., Cheng, Z.-S., Cheng, H., Deng, T., Fan, Y.-P., Fang, C., Huang, D., Huang, L.-Q., Huang, Q., 2020. A rapid advice guideline for the diagnosis and treatment of 2019 novel coronavirus (2019-nCoV) infected pneumonia (standard version). Military Medical Research 7, 4.

Ju, C.-R., Lian, Q.-Y., Zhang, J.-H., Qiu, T., Cai, Z.-T., Jiang, W.-Y., Zhang, J., Cheng, Q., Chen, G., Li, N., 2020. Recommended prophylactic and management strategies for severe acute respiratory syndrome coronavirus 2 infection in transplant recipients. Chronic Diseases and Translational Medicine.

Jung, S.-Y., Kang, K.W., Lee, E.-Y., Seo, D.-W., Kim, H.-L., Kim, H., Kwon, T., Park, H.-L., Kim, H., Lee, S.-M., Nam, J.-H., 2018. Heterologous prime-boost vaccination with adenoviral vector and protein nanoparticles induces both $\mathrm{Th} 1$ and $\mathrm{Th} 2$ responses against Middle East respiratory syndrome coronavirus. Vaccine 36, 3468-3476.

Kanne, J.P., 2020. Chest CT Findings in 2019 Novel Coronavirus (2019-nCoV) Infections from Wuhan, China: Key Points for the Radiologist. Radiology 295, 16-17. 
Kim, J.M., Chung, Y.S., Jo, H.J., Lee, N.J., Kim, M.S., Woo, S.H., Park, S., Kim, J.W., Kim, H.M., Han, M.G., 2020. Identification of Coronavirus Isolated from a Patient in Korea with COVID-19. Osong public health and research perspectives 11, 3-7.

Kocamemi, B.A., Kurt, H., Sait, A., Sarac, F., Saatci, A.M., Pakdemirli, B., 2020. SARS-CoV-2 Detection in Istanbul Wastewater Treatment Plant Sludges. medRxiv, 2020.2005.2012.20099358.

Korber, B., Fischer, W.M., Gnanakaran, S., Yoon, H., Theiler, J., Abfalterer, W., Hengartner, N., Giorgi, E.E., Bhattacharya, T., Foley, B., Hastie, K.M., Parker, M.D., Partridge, D.G., Evans, C.M., Freeman, T.M., de Silva, T.I., McDanal, C., Perez, L.G., Tang, H., Moon-Walker, A., Whelan, S.P., LaBranche, C.C., Saphire, E.O., Montefiori, D.C., 2020. Tracking Changes in SARS-CoV-2 Spike: Evidence that D614G Increases Infectivity of the COVID-19 Virus. Cell 182, 812-827.e819.

Kow, C.S., Hasan, S.S., 2020. Use of low-molecular-weight heparin in COVID-19 patients. Journal of vascular surgery. Venous and lymphatic disorders 8, 900-901.

Krysinska, K., Andriessen, K., Corveleyn, J., 2014. Religion and spirituality in online suicide bereavement: An analysis of online memorials. Crisis: The Journal of Crisis Intervention and Suicide Prevention 35, 349.

Ksiazek, T.G., Erdman, D., Goldsmith, C.S., Zaki, S.R., Peret, T., Emery, S., Tong, S., Urbani, C., Comer, J.A., Lim, W., Rollin, P.E., Dowell, S.F., Ling, A.-E., Humphrey, C.D., Shieh, W.-J., Guarner, J., Paddock, C.D., Rota, P., Fields, B., DeRisi, J., Yang, J.-Y., Cox, N., Hughes, J.M., LeDuc, J.W., Bellini, W.J., Anderson, L.J., Group, S.W., 2003. A novel coronavirus associated with severe acute respiratory syndrome. N Engl J Med 348, 1953-1966.

Kuhn, J.H., Li, W., Choe, H., Farzan, M., 2004. Angiotensin-converting enzyme 2: a functional receptor for SARS coronavirus. Cell Mol Life Sci 61, 2738-2743.

Kulcsar, K.A., Coleman, C.M., Beck, S.E., Frieman, M.B., 2019. Comorbid diabetes results in immune dysregulation and enhanced disease severity following MERS-CoV infection. JCI insight 4.

Kumar, S., Stecher, G., Tamura, K., 2016. MEGA7: molecular evolutionary genetics analysis version 7.0 for bigger datasets. Molecular biology and evolution 33, 1870-1874.

Lacroix, A., Duong, V., Hul, V., San, S., Davun, H., Omaliss, K., Chea, S., Hassanin, A., Theppangna, W., Silithammavong, S., Khammavong, K., Singhalath, S., Greatorex, Z., Fine, A.E., Goldstein, T., Olson, S., Joly, D.O., Keatts, L., Dussart, P., Afelt, A., Frutos, R., Buchy, P., 2017. Genetic diversity of coronaviruses in bats in Lao PDR and Cambodia. Infect Genet Evol 48, 10-18.

Lam, T.T.-Y., Shum, M.H.-H., Zhu, H.-C., Tong, Y.-G., Ni, X.-B., Liao, Y.-S., Wei, W., Cheung, W.Y.M., Li, W.-J., Li, L.-F., Leung, G.M., Holmes, E.C., Hu, Y.-L., Guan, Y., 2020. Identification of 2019$\mathrm{nCoV}$ related coronaviruses in Malayan pangolins in southern China. bioRxiv, 2020.2002.2013.945485.

Lei, J., Li, J., Li, X., Qi, X., 2020. CT Imaging of the 2019 Novel Coronavirus (2019-nCoV) Pneumonia. Radiology 295, 18. 
Li, B., Yang, J., Zhao, F., Zhi, L., Wang, X., Liu, L., Bi, Z., Zhao, Y., 2020a. Prevalence and impact of cardiovascular metabolic diseases on COVID-19 in China. Clinical research in cardiology : official journal of the German Cardiac Society 109, 531-538.

Li, F., 2016. Structure, function, and evolution of coronavirus spike proteins. Annual review of virology $3,237-261$.

Li, Q., Guan, X., Wu, P., Wang, X., Zhou, L., Tong, Y., Ren, R., Leung, K.S.M., Lau, E.H.Y., Wong, J.Y., Xing, X., Xiang, N., Wu, Y., Li, C., Chen, Q., Li, D., Liu, T., Zhao, J., Li, M., Tu, W., Chen, C., Jin, L., Yang, R., Wang, Q., Zhou, S., Wang, R., Liu, H., Luo, Y., Liu, Y., Shao, G., Li, H., Tao, Z., Yang, Y., Deng, Z., Liu, B., Ma, Z., Zhang, Y., Shi, G., Lam, T.T.Y., Wu, J.T.K., Gao, G.F., Cowling, B.J., Yang, B., Leung, G.M., Feng, Z., 2020b. Early Transmission Dynamics in Wuhan, China, of Novel Coronavirus-Infected Pneumonia. N Engl J Med, 10.1056/NEJMoa2001316.

Li, Q., Guan, X., Wu, P., Wang, X., Zhou, L., Tong, Y., Ren, R., Leung, K.S.M., Lau, E.H.Y., Wong, J.Y., Xing, X., Xiang, N., Wu, Y., Li, C., Chen, Q., Li, D., Liu, T., Zhao, J., Liu, M., Tu, W., Chen, C., Jin, L., Yang, R., Wang, Q., Zhou, S., Wang, R., Liu, H., Luo, Y., Liu, Y., Shao, G., Li, H., Tao, Z., Yang, Y., Deng, Z., Liu, B., Ma, Z., Zhang, Y., Shi, G., Lam, T.T.Y., Wu, J.T., Gao, G.F., Cowling, B.J., Yang, B., Leung, G.M., Feng, Z., 2020c. Early Transmission Dynamics in Wuhan, China, of Novel Coronavirus-Infected Pneumonia. N Engl J Med 382, 1199-1207.

Li, W., Moore, M.J., Vasilieva, N., Sui, J., Wong, S.K., Berne, M.A., Somasundaran, M., Sullivan, J.L., Luzuriaga, K., Greenough, T.C., 2003. Angiotensin-converting enzyme 2 is a functional receptor for the SARS coronavirus. Nature 426, 450-454.

Liu, J., Li, S., Liu, J., Liang, B., Wang, X., Wang, H., Li, W., Tong, Q., Yi, J., Zhao, L., Xiong, L., Guo, C., Tian, J., Luo, J., Yao, J., Pang, R., Shen, H., Peng, C., Liu, T., Zhang, Q., Wu, J., Xu, L., Lu, S., Wang, B., Weng, Z., Han, C., Zhu, H., Zhou, R., Zhou, H., Chen, X., Ye, P., Zhu, B., Wang, L., Zhou, W., He, S., He, Y., Jie, S., Wei, P., Zhang, J., Lu, Y., Wang, W., Zhang, L., Li, L., Zhou, F., Wang, J., Dittmer, U., Lu, M., Hu, Y., Yang, D., Zheng, X., 2020a. Longitudinal characteristics of lymphocyte responses and cytokine profiles in the peripheral blood of SARS-CoV-2 infected patients. EBioMedicine $55,102763$.

Liu, P., Chen, W., Chen, J.-P., 2019. Viral metagenomics revealed Sendai virus and coronavirus infection of Malayan pangolins (Manis javanica). Viruses 11, 979.

Liu, Y., Li, T., Deng, Y., Liu, S., Zhang, D., Li, H., Wang, X., Jia, L., Han, J., Bei, Z., Zhou, Y., Li, L., Li, J., 2020b. Stability of SARS-CoV-2 on environmental surfaces and in human excreta. medRxiv, 2020.2005.2007.20094805.

Lu, G., Hu, Y., Wang, Q., Qi, J., Gao, F., Li, Y., Zhang, Y., Zhang, W., Yuan, Y., Bao, J., Zhang, B., Shi, Y., Yan, J., Gao, G.F., 2013. Molecular basis of binding between novel human coronavirus MERS-CoV and its receptor CD26. Nature 500, 227-231.

Lu, Q., Cai, Z., Chen, B., Liu, T., 2020a. Social Policy Responses to the Covid-19 Crisis in China in 2020. International journal of environmental research and public health 17. 
Lu, Q., Cai, Z., Chen, B., Liu, T., 2020b. Social policy responses to the covid-19 crisis in China in 2020. International journal of environmental research and public health 17, 5896.

Lu, R., Zhao, X., Li, J., Niu, P., Yang, B., Wu, H., Wang, W., Song, H., Huang, B., Zhu, N., Bi, Y., Ma, X., Zhan, F., Wang, L., Hu, T., Zhou, H., Hu, Z., Zhou, W., Zhao, L., Chen, J., Meng, Y., Wang, J., Lin, Y., Yuan, J., Xie, Z., Ma, J., Liu, W.J., Wang, D., Xu, W., Holmes, E.C., Gao, G.F., Wu, G., Chen, W., Shi, W., Tan, W., 2020c. Genomic characterisation and epidemiology of 2019 novel coronavirus: implications for virus origins and receptor binding. Lancet 395, 565-574.

Luan, J., Lu, Y., Jin, X., Zhang, L., 2020. Spike protein recognition of mammalian ACE2 predicts the host range and an optimized ACE2 for SARS-CoV-2 infection. Biochemical and biophysical research communications.

Mackay, I.M., 2004. Real-time PCR in the microbiology laboratory. Clinical Microbiology and Infection $10,190-212$.

Mahase, E., 2020a. Covid-19: Russia approves vaccine without large scale testing or published results. Bmj 370, m3205.

Mahase, E., 2020b. Covid-19: Where are we on immunity and vaccines? Bmj 370, m3096.

Maigari, Y.T., 2016. The relevance of the Islamic principles on cleanliness to contemporary times: focus on hand washing. Ilorin Journal of Religious Studies 6, 91-104.

Manohar, P., Loh, B., Athira, S., Nachimuthu, R., Hua, X., Welburn, S.C., Leptihn, S., 2020. Secondary Bacterial Infections During Pulmonary Viral Disease: Phage Therapeutics as Alternatives to Antibiotics? Frontiers in microbiology 11, 1434.

Marmor, M.F., Carr, R.E., Easterbrook, M., Farjo, A.A., Mieler, W.F., 2002. Recommendations on screening for chloroquine and hydroxychloroquine retinopathy: a report by the American Academy of Ophthalmology. Ophthalmology 109, 1377-1382.

Masters, P.S., 2006. The molecular biology of coronaviruses. Adv Virus Res 66, 193-292.

Medema, G., Heijnen, L., Elsinga, G., Italiaander, R., Brouwer, A., 2020. Presence of SARSCoronavirus-2 RNA in Sewage and Correlation with Reported COVID-19 Prevalence in the Early Stage of the Epidemic in The Netherlands. Environ Sci Technol Lett, acs.estlett.0c00357.

Michetti, C.P., Burlew, C.C., Bulger, E.M., Davis, K.A., Spain, D.A., 2020. Performing tracheostomy during the Covid-19 pandemic: guidance and recommendations from the Critical Care and Acute Care Surgery Committees of the American Association for the Surgery of Trauma. Trauma Surgery \& Acute Care Open 5, e000482.

Millán-Oñate, J., Millan, W., Mendoza, L.A., Sánchez, C.G., Fernandez-Suarez, H., Bonilla-Aldana, D.K., Rodríguez-Morales, A.J., 2020. Successful recovery of COVID-19 pneumonia in a patient from Colombia after receiving chloroquine and clarithromycin. Annals of clinical microbiology and antimicrobials 19, 16. 
Mueller, A.L., McNamara, M.S., Sinclair, D.A., 2020. Why does COVID-19 disproportionately affect older people? Aging 12, 9959-9981.

Mullard, A., 2020. COVID-19 vaccine development pipeline gears up. The Lancet 395, 1751-1752.

Munster, V.J., Koopmans, M., van Doremalen, N., van Riel, D., de Wit, E., 2020. A Novel Coronavirus Emerging in China - Key Questions for Impact Assessment. N Engl J Med, 10.1056/NEJMp2000929.

Muthumani, K., Falzarano, D., Reuschel, E.L., Tingey, C., Flingai, S., Villarreal, D.O., Wise, M., Patel, A., Izmirly, A., Aljuaid, A., Seliga, A.M., Soule, G., Morrow, M., Kraynyak, K.A., Khan, A.S., Scott, D.P., Feldmann, F., LaCasse, R., Meade-White, K., Okumura, A., Ugen, K.E., Sardesai, N.Y., Kim, J.J., Kobinger, G., Feldmann, H., Weiner, D.B., 2015. A synthetic consensus anti-spike protein DNA vaccine induces protective immunity against Middle East respiratory syndrome coronavirus in nonhuman primates. Sci Transl Med 7, 301ra132-301ra132.

Nagy, P.D., Simon, A.E., 1997. New insights into the mechanisms of RNA recombination. Virology 235, $1-9$.

Naicker, S., Yang, C.W., Hwang, S.J., Liu, B.C., Chen, J.H., Jha, V., 2020. The Novel Coronavirus 2019 epidemic and kidneys. Kidney international 97, 824-828.

Negri, E.M., Piloto, B.M., Morinaga, L.K., Jardim, C.V.P., Lamy, S.A.E., Ferreira, M.A., D'Amico, E.A., Deheinzelin, D., 2020. Heparin Therapy Improving Hypoxia in COVID-19 Patients - A Case Series. Frontiers in physiology 11, 573044.

Nikolich-Zugich, J., Knox, K.S., Rios, C.T., Natt, B., Bhattacharya, D., Fain, M.J., 2020. SARS-CoV-2 and COVID-19 in older adults: what we may expect regarding pathogenesis, immune responses, and outcomes. GeroScience 42, 505-514.

Oliver, S.E., Gargano, J.W., Marin, M., Wallace, M., Curran, K.G., Chamberland, M., McClung, N., Campos-Outcalt, D., Morgan, R.L., Mbaeyi, S., Romero, J.R., Talbot, H.K., Lee, G.M., Bell, B.P., Dooling, K., 2020. The Advisory Committee on Immunization Practices' Interim Recommendation for Use of Pfizer-BioNTech COVID-19 Vaccine - United States, December 2020. MMWR. Morbidity and mortality weekly report $69,1922-1924$.

Pan, Y., Guan, H., Zhou, S., Wang, Y., Li, Q., Zhu, T., Hu, Q., Xia, L., 2020. Initial CT findings and temporal changes in patients with the novel coronavirus pneumonia (2019-nCoV): a study of 63 patients in Wuhan, China. European radiology.

Paules, C.I., Marston, H.D., Fauci, A.S., 2020. Coronavirus infections - more than just the common cold. Jama 323, 707-708.

Phan, L.T., Nguyen, T.V., Luong, Q.C., Nguyen, T.V., Nguyen, H.T., Le, H.Q., Nguyen, T.T., Cao, T.M., Pham, Q.D., 2020. Importation and Human-to-Human Transmission of a Novel Coronavirus in Vietnam. N Engl J Med, 10.1056/NEJMc2001272.

Plowright, R.K., Eby, P., Hudson, P.J., Smith, I.L., Westcott, D., Bryden, W.L., Middleton, D., Reid, P.A., McFarlane, R.A., Martin, G., Tabor, G.M., Skerratt, L.F., Anderson, D.L., Crameri, G., Quammen, 
D., Jordan, D., Freeman, P., Wang, L.-F., Epstein, J.H., Marsh, G.A., Kung, N.Y., McCallum, H., 2015. Ecological dynamics of emerging bat virus spillover. Proc Biol Sci 282, 20142124-20142124.

Poon, L.L.M., Chu, D.K.W., Chan, K.H., Wong, O.K., Ellis, T.M., Leung, Y.H.C., Lau, S.K.P., Woo, P.C.Y., Suen, K.Y., Yuen, K.Y., Guan, Y., Peiris, J.S.M., 2005. Identification of a novel coronavirus in bats. J Virol 79, 2001-2009.

Poutanen, S.M., Low, D.E., Henry, B., Finkelstein, S., Rose, D., Green, K., Tellier, R., Draker, R., Adachi, D., Ayers, M., Chan, A.K., Skowronski, D.M., Salit, I., Simor, A.E., Slutsky, A.S., Doyle, P.W., Krajden, M., Petric, M., Brunham, R.C., McGeer, A.J., National Microbiology Laboratory, C., Canadian Severe Acute Respiratory Syndrome Study, T., 2003. Identification of severe acute respiratory syndrome in Canada. N Engl J Med 348, 1995-2005.

Project, V.K., 2021. COVID-19 vaccines. https://vk.ovg.ox.ac.uk/vk/covid-19-vaccines.

Pyrc, K., Berkhout, B., van der Hoek, L., 2007. The novel human coronaviruses NL63 and HKU1. J Virol 81, 3051-3057.

Race, M., Ferraro, A., Galdiero, E., Guida, M., Núñez-Delgado, A., Pirozzi, F., Siciliano, A., Fabbricino, M., 2020. Current emerging SARS-CoV-2 pandemic: Potential direct/indirect negative impacts of virus persistence and related therapeutic drugs on the aquatic compartments. Environmental research 188, 109808.

Raj, V.S., Mou, H., Smits, S.L., Dekkers, D.H.W., Müller, M.A., Dijkman, R., Muth, D., Demmers, J.A.A., Zaki, A., Fouchier, R.A.M., Thiel, V., Drosten, C., Rottier, P.J.M., Osterhaus, A.D.M.E., Bosch, B.J., Haagmans, B.L., 2013. Dipeptidyl peptidase 4 is a functional receptor for the emerging human coronavirus-EMC. Nature 495, 251-254.

Read, J.M., Bridgen, J.R.E., Cummings, D.A.T., Ho, A., Jewell, C.P., 2020. Novel coronavirus 2019$\mathrm{nCoV}$ : early estimation of epidemiological parameters and epidemic predictions. medRxiv, 2020.2001.2023.20018549.

Sabir, J.S.M., Lam, T.T.Y., Ahmed, M.M.M., Li, L., Shen, Y., Abo-Aba, S.E.M., Qureshi, M.I., AbuZeid, M., Zhang, Y., Khiyami, M.A., Alharbi, N.S., Hajrah, N.H., Sabir, M.J., Mutwakil, M.H.Z., Kabli, S.A., Alsulaimany, F.A.S., Obaid, A.Y., Zhou, B., Smith, D.K., Holmes, E.C., Zhu, H., Guan, Y., 2016. Co-circulation of three camel coronavirus species and recombination of MERS-CoVs in Saudi Arabia. Science 351, 81-84.

Scohy, A., Anantharajah, A., Bodéus, M., Kabamba-Mukadi, B., Verroken, A., Rodriguez-Villalobos, H., 2020. Low performance of rapid antigen detection test as frontline testing for COVID-19 diagnosis. Journal of clinical virology : the official publication of the Pan American Society for Clinical Virology $129,104455$.

Sheahan, T.P., Sims, A.C., Graham, R.L., Menachery, V.D., Gralinski, L.E., Case, J.B., Leist, S.R., Pyrc, K., Feng, J.Y., Trantcheva, I., Bannister, R., Park, Y., Babusis, D., Clarke, M.O., Mackman, R.L., Spahn, J.E., Palmiotti, C.A., Siegel, D., Ray, A.S., Cihlar, T., Jordan, R., Denison, M.R., Baric, R.S., 2017. Broad-spectrum antiviral GS-5734 inhibits both epidemic and zoonotic coronaviruses. Sci Trans1 Med 9, eaal3653. 
Sheahan, T.P., Sims, A.C., Leist, S.R., Schäfer, A., Won, J., Brown, A.J., Montgomery, S.A., Hogg, A., Babusis, D., Clarke, M.O., Spahn, J.E., Bauer, L., Sellers, S., Porter, D., Feng, J.Y., Cihlar, T., Jordan, R., Denison, M.R., Baric, R.S., 2020. Comparative therapeutic efficacy of remdesivir and combination lopinavir, ritonavir, and interferon beta against MERS-CoV. Nat Commun 11, 222-222.

Shi, J., Wen, Z., Zhong, G., Yang, H., Wang, C., Huang, B., Liu, R., He, X., Shuai, L., Sun, Z., Zhao, Y., Liu, P., Liang, L., Cui, P., Wang, J., Zhang, X., Guan, Y., Tan, W., Wu, G., Chen, H., Bu, Z., 2020a. Susceptibility of ferrets, cats, dogs, and other domesticated animals to SARS-coronavirus 2. Science.

Shi, Y., Wang, Y., Shao, C., Huang, J., Gan, J., Huang, X., Bucci, E., Piacentini, M., Ippolito, G., Melino, G., 2020b. COVID-19 infection: the perspectives on immune responses. Cell death and differentiation 27, 1451-1454.

Simmons, G., Gosalia, D.N., Rennekamp, A.J., Reeves, J.D., Diamond, S.L., Bates, P., 2005. Inhibitors of cathepsin L prevent severe acute respiratory syndrome coronavirus entry. Proceedings of the National Academy of Sciences 102, 11876-11881.

Sinclair, R., Boone, S.A., Greenberg, D., Keim, P., Gerba, C.P., 2008. Persistence of category A select agents in the environment. Appl Environ Microbiol 74, 555-563.

Song, F., Fux, R., Provacia, L.B., Volz, A., Eickmann, M., Becker, S., Osterhaus, A.D.M.E., Haagmans, B.L., Sutter, G., 2013. Middle East respiratory syndrome coronavirus spike protein delivered by modified vaccinia virus Ankara efficiently induces virus-neutralizing antibodies. J Virol 87, 11950-11954.

Song, H.-D., Tu, C.-C., Zhang, G.-W., Wang, S.-Y., Zheng, K., Lei, L.-C., Chen, Q.-X., Gao, Y.-W., Zhou, H.-Q., Xiang, H., Zheng, H.-J., Chern, S.-W.W., Cheng, F., Pan, C.-M., Xuan, H., Chen, S.-J., Luo, H.-M., Zhou, D.-H., Liu, Y.-F., He, J.-F., Qin, P.-Z., Li, L.-H., Ren, Y.-Q., Liang, W.-J., Yu, Y.-D., Anderson, L., Wang, M., Xu, R.-H., Wu, X.-W., Zheng, H.-Y., Chen, J.-D., Liang, G., Gao, Y., Liao, M., Fang, L., Jiang, L.-Y., Li, H., Chen, F., Di, B., He, L.-J., Lin, J.-Y., Tong, S., Kong, X., Du, L., Hao, P., Tang, H., Bernini, A., Yu, X.-J., Spiga, O., Guo, Z.-M., Pan, H.-Y., He, W.-Z., Manuguerra, J.-C., Fontanet, A., Danchin, A., Niccolai, N., Li, Y.-X., Wu, C.-I., Zhao, G.-P., 2005. Cross-host evolution of severe acute respiratory syndrome coronavirus in palm civet and human. Proc Natl Acad Sci U S A 102, $2430-2435$.

Song, H.C., Seo, M.-Y., Stadler, K., Yoo, B.J., Choo, Q.-L., Coates, S.R., Uematsu, Y., Harada, T., Greer, C.E., Polo, J.M., 2004. Synthesis and characterization of a native, oligomeric form of recombinant severe acute respiratory syndrome coronavirus spike glycoprotein. J Virol 78, 10328-10335.

Song, W., Gui, M., Wang, X., Xiang, Y., 2018. Cryo-EM structure of the SARS coronavirus spike glycoprotein in complex with its host cell receptor ACE2. PLoS Pathog 14, e1007236.

Stefan, N., Birkenfeld, A.L., Schulze, M.B., Ludwig, D.S., 2020. Obesity and impaired metabolic health in patients with COVID-19. Nature reviews. Endocrinology 16, 341-342.

Su, S., Wong, G., Shi, W., Liu, J., Lai, A.C.K., Zhou, J., Liu, W., Bi, Y., Gao, G.F., 2016. Epidemiology, Genetic Recombination, and Pathogenesis of Coronaviruses. Trends Microbiol 24, 490-502. 
Technology, P., 2020. Coronavirus incubation period could be 27 days, shows data, https://www.pharmaceutical-technology.com/news/coronavirus-incubation-period-27-days/.

Thor, S.W., Hilt, D.A., Kissinger, J.C., Paterson, A.H., Jackwood, M.W., 2011. Recombination in avian gamma-coronavirus infectious bronchitis virus. Viruses 3, 1777-1799.

Tran, H.N., Le, G.T., Nguyen, D.T., Juang, R.S., Rinklebe, J., Bhatnagar, A., Lima, E.C., Iqbal, H.M.N., Sarmah, A.K., Chao, H.P., 2021. SARS-CoV-2 coronavirus in water and wastewater: A critical review about presence and concern. Environmental research 193, 110265.

UNWTO, 2020. UNWTO Statement on the Novel Coronavirus Outbreak. https://www.unwto.org/unwtostatement-on-the-novel-coronavirus-outbreak.

Vaillant, G.E., 2013. Psychiatry, religion, positive emotions and spirituality. Asian journal of psychiatry $6,590-594$.

Van Doremalen, N., Bushmaker, T., Morris, D.H., Holbrook, M.G., Gamble, A., Williamson, B.N., Tamin, A., Harcourt, J.L., Thornburg, N.J., Gerber, S.I., 2020. Aerosol and surface stability of SARSCoV-2 as compared with SARS-CoV-1. New England Journal of Medicine 382, 1564-1567.

Van Hemert, M.J., Van Den Worm, S.H., Knoops, K., Mommaas, A.M., Gorbalenya, A.E., Snijder, E.J., 2008. SARS-coronavirus replication/transcription complexes are membrane-protected and need a host factor for activity in vitro. PLoS Pathog 4, e1000054.

ViralZone, Deltacoronavirus, in: https://viralzone.expasy.org/3137 (Ed.), https://viralzone.expasy.org/3137. https://viralzone.expasy.org/3137.

Walls, A.C., Park, Y.J., Tortorici, M.A., Wall, A., McGuire, A.T., Veesler, D., 2020. Structure, Function, and Antigenicity of the SARS-CoV-2 Spike Glycoprotein. Cell.

Wang, C., Horby, P.W., Hayden, F.G., Gao, G.F., 2020a. A novel coronavirus outbreak of global health concern. Lancet, S0140-6736(0120)30185-30189.

Wang, C., Zheng, X., Gai, W., Zhao, Y., Wang, H., Wang, H., Feng, N., Chi, H., Qiu, B., Li, N., Wang, T., Gao, Y., Yang, S., Xia, X., 2017. MERS-CoV virus-like particles produced in insect cells induce specific humoural and cellular imminity in rhesus macaques. Oncotarget 8, 12686-12694.

Wang, D., Hu, B., Hu, C., Zhu, F., Liu, X., Zhang, J., Wang, B., Xiang, H., Cheng, Z., Xiong, Y., Zhao, Y., Li, Y., Wang, X., Peng, Z., 2020b. Clinical Characteristics of 138 Hospitalized Patients With 2019 Novel Coronavirus-Infected Pneumonia in Wuhan, China. Jama 323, 1061-1069.

Wang, J.T., Sheng, W.H., Fang, C.T., Chen, Y.C., Wang, J.L., Yu, C.J., Chang, S.C., Yang, P.C., 2004. Clinical manifestations, laboratory findings, and treatment outcomes of SARS patients. Emerg Infect Dis $10,818-824$.

Wang, L., Shi, W., Joyce, M.G., Modjarrad, K., Zhang, Y., Leung, K., Lees, C.R., Zhou, T., Yassine, H.M., Kanekiyo, M., Yang, Z.-y., Chen, X., Becker, M.M., Freeman, M., Vogel, L., Johnson, J.C., Olinger, G., Todd, J.P., Bagci, U., Solomon, J., Mollura, D.J., Hensley, L., Jahrling, P., Denison, M.R., 
Rao, S.S., Subbarao, K., Kwong, P.D., Mascola, J.R., Kong, W.-P., Graham, B.S., 2015. Evaluation of candidate vaccine approaches for MERS-CoV. Nat Commun 6, 7712-7712.

Wang, M., Cao, R., Zhang, L., Yang, X., Liu, J., Xu, M., Shi, Z., Hu, Z., Zhong, W., Xiao, G., 2020c. Remdesivir and chloroquine effectively inhibit the recently emerged novel coronavirus $(2019-\mathrm{nCoV})$ in vitro. Cell Res, 10.1038/s41422-41020-40282-41420.

Wang, N., Li, S.-Y., Yang, X.-L., Huang, H.-M., Zhang, Y.-J., Guo, H., Luo, C.-M., Miller, M., Zhu, G., Chmura, A.A., Hagan, E., Zhou, J.-H., Zhang, Y.-Z., Wang, L.-F., Daszak, P., Shi, Z.-L., 2018.

Serological Evidence of Bat SARS-Related Coronavirus Infection in Humans, China. Virol Sin 33, $104-$ 107.

Wang, Q., Li, C., Zhang, Q., Wang, T., Li, J., Guan, W., Yu, J., Liang, M., Li, D., 2010. Interactions of SARS coronavirus nucleocapsid protein with the host cell proteasome subunit p42. Virology journal 7, 18.

Wang, X.W., Li, J.S., Jin, M., Zhen, B., Kong, Q.X., Song, N., Xiao, W.J., Yin, J., Wei, W., Wang, G.J., Si, B.Y., Guo, B.Z., Liu, C., Ou, G.R., Wang, M.N., Fang, T.Y., Chao, F.H., Li, J.W., 2005. Study on the resistance of severe acute respiratory syndrome-associated coronavirus. Journal of virological methods $126,171-177$.

Weiss, S.R., Leibowitz, J.L., 2011. Coronavirus pathogenesis. Adv Virus Res 81, 85-164.

WHO, 2019. Middle East respiratory syndrome coronavirus (MERS-CoV). https://www.who.int/newsroom/fact-sheets/detail/middle-east-respiratory-syndrome-coronavirus-(mers-cov).

WHO, 2020a. Coronavirus Disease 2019(COVID-19): situation report-28. 2020. https://www.who.int/docs/default-source/coronaviruse/situation-reports/20200217-sitrep-28-covid19.pdf?sfvrsn=a19cf2ad_2, 200490.

WHO, 2020b. DRAFT landscape of COVID-19 candidate vaccines -18 February 2020.

https://www.who.int/blueprint/priority-diseases/key-action/list-of-candidate-vaccines-developed-againstncov.pdf.

WHO, 2020c. Novel Coronavirus - China. . https:/www.who.int/csr/don/12-january-2020-novelcoronavirus-china/en/.

WHO, 2020d. Pneumonia of unknown cause - China. https://www.who.int/csr/don/05-january-2020pneumonia-of-unkown-cause-china/en/.

WHO, 2021. The Oxford/AstraZeneca COVID-19 vaccine: what you need to know. https://www.who.int/news-room/feature-stories/detail/the-oxford-astrazeneca-covid-19-vaccine-whatyou-need-to-know.

Wikipedia, 2020. Oxford-AstraZeneca COVID-19 vaccine. https://en.wikipedia.org/wiki/Oxford\%E2\%80\%93AstraZeneca_COVID-19 vaccine\#cite_noteAU TGA decision-1. 
Wong, A.C.P., Li, X., Lau, S.K.P., Woo, P.C.Y., 2019. Global Epidemiology of Bat Coronaviruses. Viruses 11, 174.

Woo, P.C.Y., Lau, S.K.P., Lam, C.S.F., Lau, C.C.Y., Tsang, A.K.L., Lau, J.H.N., Bai, R., Teng, J.L.L., Tsang, C.C.C., Wang, M., Zheng, B.-J., Chan, K.-H., Yuen, K.-Y., 2012. Discovery of seven novel Mammalian and avian coronaviruses in the genus deltacoronavirus supports bat coronaviruses as the gene source of alphacoronavirus and betacoronavirus and avian coronaviruses as the gene source of gammacoronavirus and deltacoronavirus. J Virol 86, 3995-4008.

Worldometer, 2020a. Coronavirus Cases as of 10 july 2020. https:/www.worldometers.info/coronavirus/.

Worldometer, 2020b. Coronavirus Cases:. https://www.worldometers.info/coronavirus/country/china/.

Wrapp, D., McLellan, J.S., 2019. The 3.1-Angstrom Cryo-electron Microscopy Structure of the Porcine Epidemic Diarrhea Virus Spike Protein in the Prefusion Conformation. J Virol 93.

Wu, Z., Yang, L., Ren, X., Zhang, J., Yang, F., Zhang, S., Jin, Q., 2016. ORF8-Related Genetic Evidence for Chinese Horseshoe Bats as the Source of Human Severe Acute Respiratory Syndrome Coronavirus. J Infect Dis 213, 579-583.

Xu, J., Jia, W., Wang, P., Zhang, S., Shi, X., Wang, X., Zhang, L., 2019. Antibodies and vaccines against Middle East respiratory syndrome coronavirus. Emerg Microbes Infect 8, 841-856.

Xu, T.L., Ao, M.Y., Zhou, X., Zhu, W.F., Nie, H.Y., Fang, J.H., Sun, X., Zheng, B., Chen, X.F., 2020. China's practice to prevent and control COVID-19 in the context of large population movement. Infectious diseases of poverty $9,115$.

Xu, X., Chen, P., Wang, J., Feng, J., Zhou, H., Li, X., Zhong, W., Hao, P., 2020a. Evolution of the novel coronavirus from the ongoing Wuhan outbreak and modeling of its spike protein for risk of human transmission. Science China. Life sciences 63, 457-460.

Yang, X.-L., Hu, B., Wang, B., Wang, M.-N., Zhang, Q., Zhang, W., Wu, L.-J., Ge, X.-Y., Zhang, Y.-Z., Daszak, P., Wang, L.-F., Shi, Z.-L., 2015. Isolation and Characterization of a Novel Bat Coronavirus Closely Related to the Direct Progenitor of Severe Acute Respiratory Syndrome Coronavirus. J Virol 90, 3253-3256.

Yang, X., Yu, Y., Xu, J., Shu, H., Xia, J., Liu, H., Wu, Y., Zhang, L., Yu, Z., Fang, M., Yu, T., Wang, Y., Pan, S., Zou, X., Yuan, S., Shang, Y., 2020a. Clinical course and outcomes of critically ill patients with SARS-CoV-2 pneumonia in Wuhan, China: a single-centered, retrospective, observational study. The Lancet. Respiratory medicine 8, 475-481.

Yang, Y., Islam, M.S., Wang, J., Li, Y., Chen, X., 2020b. Traditional Chinese Medicine in the Treatment of Patients Infected with 2019-New Coronavirus (SARS-CoV-2): A Review and Perspective. International journal of biological sciences 16, 1708-1717.

Yang, Y., Lu, Q., Liu, M., Wang, Y., Zhang, A., Jalali, N., Dean, N., Longini, I., Halloran, M.E., Xu, B., 2020c. Epidemiological and clinical features of the 2019 novel coronavirus outbreak in China. MedRxiv. 
Yao, X., Ye, F., Zhang, M., Cui, C., Huang, B., Niu, P., Liu, X., Zhao, L., Dong, E., Song, C., 2020. In vitro antiviral activity and projection of optimized dosing design of hydroxychloroquine for the treatment of severe acute respiratory syndrome coronavirus 2 (SARS-CoV-2). Clinical Infectious Diseases.

Ye, Z.W., Yuan, S., Yuen, K.S., Fung, S.Y., Chan, C.P., Jin, D.Y., 2020. Zoonotic origins of human coronaviruses. International journal of biological sciences 16, 1686-1697.

Yeo, C., Kaushal, S., Yeo, D., 2020. Enteric involvement of coronaviruses: is faecal-oral transmission of SARS-CoV-2 possible? The lancet. Gastroenterology \& hepatology 5, 335-337.

Yi, Y., Lagniton, P.N.P., Ye, S., Li, E., Xu, R.H., 2020. COVID-19: what has been learned and to be learned about the novel coronavirus disease. International journal of biological sciences 16, 1753-1766.

Yu, I.T., Li, Y., Wong, T.W., Tam, W., Chan, A.T., Lee, J.H., Leung, D.Y., Ho, T., 2004. Evidence of airborne transmission of the severe acute respiratory syndrome virus. New England Journal of Medicine 350, 1731-1739.

Yuan, S., Jiang, S.C., Li, Z.L., 2020. Analysis of Possible Intermediate Hosts of the New Coronavirus SARS-CoV-2. Frontiers in veterinary science 7, 379.

Zaki, A.M., van Boheemen, S., Bestebroer, T.M., Osterhaus, A.D.M.E., Fouchier, R.A.M., 2012. Isolation of a novel coronavirus from a man with pneumonia in Saudi Arabia. N Engl J Med 367, 18141820.

Zhang, J., Ma, X., Yu, F., Liu, J., Zou, F., Pan, T., Zhang, H., 2020. Teicoplanin potently blocks the cell entry of 2019-nCoV. BioRxiv.

Zhao, J., Tian, S., Yang, J., Liu, J., Zhang, W., 2020. Investigating the mechanism of Qing-Fei-Pai-DuTang for the treatment of Novel Coronavirus Pneumonia by network pharmacology; 2020.

Zhong, N.S., Zheng, B.J., Li, Y.M., Poon, Xie, Z.H., Chan, K.H., Li, P.H., Tan, S.Y., Chang, Q., Xie, J.P., Liu, X.Q., Xu, J., Li, D.X., Yuen, K.Y., Peiris, Guan, Y., 2003. Epidemiology and cause of severe acute respiratory syndrome (SARS) in Guangdong, People's Republic of China, in February, 2003. Lancet $362,1353-1358$.

Zhou, F., Yu, T., Du, R., Fan, G., Liu, Y., Liu, Z., Xiang, J., Wang, Y., Song, B., Gu, X., Guan, L., Wei, Y., Li, H., Wu, X., Xu, J., Tu, S., Zhang, Y., Chen, H., Cao, B., 2020a. Clinical course and risk factors for mortality of adult inpatients with COVID-19 in Wuhan, China: a retrospective cohort study. Lancet 395, 1054-1062.

Zhou, P., Fan, H., Lan, T., Yang, X.-L., Shi, W.-F., Zhang, W., Zhu, Y., Zhang, Y.-W., Xie, Q.-M., Mani, S., Zheng, X.-S., Li, B., Li, J.-M., Guo, H., Pei, G.-Q., An, X.-P., Chen, J.-W., Zhou, L., Mai, K.-J., Wu, Z.-X., Li, D., Anderson, D.E., Zhang, L.-B., Li, S.-Y., Mi, Z.-Q., He, T.-T., Cong, F., Guo, P.-J., Huang, R., Luo, Y., Liu, X.-L., Chen, J., Huang, Y., Sun, Q., Zhang, X.-L.-L., Wang, Y.-Y., Xing, S.-Z., Chen, Y.-S., Sun, Y., Li, J., Daszak, P., Wang, L.-F., Shi, Z.-L., Tong, Y.-G., Ma, J.-Y., 2018. Fatal swine acute diarrhoea syndrome caused by an HKU2-related coronavirus of bat origin. Nature 556, 255-258. 
Zhou, P., Yang, X.-L., Wang, X.-G., Hu, B., Zhang, L., Zhang, W., Si, H.-R., Zhu, Y., Li, B., Huang, C.L., Chen, H.-D., Chen, J., Luo, Y., Guo, H., Jiang, R.-D., Liu, M.-Q., Chen, Y., Shen, X.-R., Wang, X., Zheng, X.-S., Zhao, K., Chen, Q.-J., Deng, F., Liu, L.-L., Yan, B., Zhan, F.-X., Wang, Y.-Y., Xiao, G.-F., Shi, Z.-L., 2020b. A pneumonia outbreak associated with a new coronavirus of probable bat origin.

Nature, 10.1038/s41586-41020-42012-41587.

Zhu, N., Zhang, D., Wang, W., Li, X., Yang, B., Song, J., Zhao, X., Huang, B., Shi, W., Lu, R., Niu, P., Zhan, F., Ma, X., Wang, D., Xu, W., Wu, G., Gao, G.F., Tan, W., China Novel Coronavirus, I., Research, T., 2020. A Novel Coronavirus from Patients with Pneumonia in China, 2019. N Engl J Med, 10.1056/NEJMoa2001017.

Zou, H., He, T., Chen, X., 2019. Tetrandrine inhibits differentiation of proinflammatory subsets of T helper cells but spares de novo differentiation of iTreg cells. International immunopharmacology 69, 307312.

Zu, Z.Y., Jiang, M.D., Xu, P.P., Chen, W., Ni, Q.Q., Lu, G.M., Zhang, L.J., 2020. Coronavirus Disease 2019 (COVID-19): A Perspective from China. Radiology, 200490. 